\title{
Review Article \\ Translational Research: From Biological Discovery to Public Benefit (or Not)
}

\author{
Michael R. Emmert-Buck \\ Avoneaux Medical Institute, Oxford, MD 21654, USA \\ Correspondence should be addressed to Michael R. Emmert-Buck; mikeeb@atlanticbb.net
}

Received 18 February 2014; Revised 14 May 2014; Accepted 14 May 2014; Published 30 June 2014

Academic Editor: Dušan Kordiš

Copyright (C) 2014 Michael R. Emmert-Buck. This is an open access article distributed under the Creative Commons Attribution License, which permits unrestricted use, distribution, and reproduction in any medium, provided the original work is properly cited.

Advances in biology are occurring at a breathtaking pace today, from genetic insights facilitated by the Human Genome Project and next generation DNA sequencing technologies, to global nucleic acid and proteomic expression measurement using new high-throughput methods. Less publicized in recent years, yet still the central driver of progress, are the steadily proceeding biological insights gained through tried and true hypothesis-driven investigation into the complex worlds of metabolism, growth, development, and regulation. Certainly, the basic science ecosystem is productive and this portends well for the myriad new applications that will benefit mankind; drugs, vaccines, devices, and related economic growth - or perhaps not-in stark contrast to the generation of fundamental biological knowledge are inefficiencies in applying this information to real-world problems, especially those of the clinic. While investigation hums along at light speed, translation often does not. The good news is that obstacles to progress are tractable. The bad news, however, is that these problems are difficult. The present paper examines translational research from multiple perspectives, beginning with a historical account and proceeding to the current state of the art. Included are descriptions of successes and challenges, along with conjecture on how the field may need to evolve in the future.

\section{Introduction}

Our greatest glory is not in never failing, but in rising up every time we fail. (Ralph Waldo Emerson)

Nothing exemplifies the quote above from Emerson more than the translation of a biological discovery into a new drug, device, or other intervention that helps society. This is no easy task.

The stakes here are high-human health and wellbeing; thus it is important that the translational system is critically examined and understood in order to maximize the likelihood that basic research performed in the laboratory and clinic benefits the public [1-7] (see Appendix for relevant websites). Moreover, if positive economic activity is generated this strengthens the biotechnology and pharmaceutical company sectors, which in turn grows the scientific ecosystem writ large, ultimately making more funds available for research and training, creating high-level jobs, and increasing appreciation of the overall enterprise by the public [8-10].
At the outset, it is important to recognize three important aspects of translational research as it is performed today.

First, the system is not broken per se as there are many advances to celebrate, exemplified by the discovery, production, and distribution of new medicines, antibiotics to treat bacterial infections and insulin to manage diabetes as two classic examples which are wonderful success stories.

Second, the endeavor is exceptionally challenging [1117]. This aspect should not be minimized. The undertaking is difficult and failure is frequent. It is easy to sit on the sidelines and find fault with the scientific research enterprise or specific translational components, but this is not helpful. What is useful is to honestly assess current principles and procedures and then to ideate and test alterations that will improve efficiency in the future.

Finally, the fact that translational research is both important and difficult calls for and even demands a maximally effective system. In many instances, solving the biological and medical matters at hand will be problematic in the best of circumstances and straightforward answers will not be 
forthcoming. But the public and patients, current and future, need this process to work well; thus investigators need to be imaginative in the ways they pursue science that will benefit the public [18-24].

What might translational research look like moving forward?

Of course, predicting the future is always risky as there are numerous unknowns to account for. However, looking ahead, one might expect to see the formation of radical new organizations. These structures will not simply be updated versions of today's academic, government, and commercial entities, since they carry with them much historical baggage, but new rationally designed entities that specifically address the relevant challenges-silos, cultures, environments, models, incentives, bureaucracy, and access for young investigators. The goal of these future institutions will be to replace, improve, or augment methods used today, leaving no dogma unexamined in the process. Although sweeping changes in translational structures may be necessary and valuable, one should not foolishly ignore the positive lessons of the past; indeed, moving ahead it is better to understand and build upon today's successful systems-observe, measure, hypothesize, analyze, improve, and repeat.

A particular danger when examining the overall biomedical research landscape is to either conflate basic science and translational research, or to play the two against each other. The disciplines are distinct sides of the same coin, and not a mutually exclusive, zero-sum game. Diminishing the value of either activity, which often occurs as arguments regarding resources and funding, will have a clear outcome-it will alter the title of this paper from a concerned questioning (or Not) toward a declarative statement (No Chance).

The situation is nuanced when it comes to the relative value of basic and translational research. Certainly, there were impressive and dazzling biological discoveries in the twentieth and early twenty-first centuries to which the proponents of basic science can point as markers of success and progress. And much good has resulted in society based on these efforts. Yet critics trenchantly assert that the medical and societal payoff has been suboptimal and slow, especially for some of the more common illnesses, and that rational application of new knowledge into therapies, most hopefully embodied today in terms such as personalized and precision medicine, has only minimally materialized. Perhaps the scientific community thought that the biological advances of the past 50-100 years would easily and automatically lead to cures for most or all diseases. They have not. Yet they have absolutely set the stage for great applications to come-the question is not if these wonderful biological insights will be translated into useful drugs and medical devices, but when, which reflects back to the efficiency of the system as a whole.

It seems that a new approach to the process of translation is needed, one that is as much inventive and creative as analytic. Ideally, it would be performed by investigators with a wide breadth of knowledge and expertise; by those who continue to push the boundaries of basic knowledge because they are puzzled by and interested in nature; by those who are willing to leave their comfort zones to continually learn new fields; and, perhaps most importantly, by those who see the freedom and financial support they receive to pursue biomedical science as a gift, one that comes with an internal price tag and social responsibility, to ensure the new basic knowledge they generate helps patients and the public, urgently, as soon as possible, by whatever means necessary. Not instead of basic research, not in place of curiosity-driven science, but in addition to it, as a direct return to those who provide the support.

The goal of the present paper is to briefly review the history and principles of translational research. More importantly, the aim is to evaluate the craft as it is practiced today. And then most importantly, to ponder ways it could be better practiced tomorrow.

\section{Definitions}

Terminology Matters. To ensure proper communication it is necessary to agree upon definitions, especially in translational research since much of the jargon that touches upon the field is used inexactly, with varying connotations and interpretations $[25,26]$. Moreover, there are several distinct yet overlapping perspectives from which to view the activity.

As a Process. Translational research is thought of broadly as the progression of a new scientific insight or discovery into a useful product, medicine, or other societal interventions. The endeavor covers all areas of science, from biological to physical to social, and essentially any effort to create public benefit from studies utilizing the scientific method fit into this category. The process can be divided into sequential subcomponents, often referred to as the T1 and T2 phases, although others have developed a more in-depth definition that includes additional phases (see Appendix). T1 is the development of a concept/discovery into a useful product or procedure, whereas T2 refers to the widespread adoption of that product/procedure by the public.

Under the broad umbrella of translational research are subcategories related to specific fields. The definitions here are fuzzy, but generally translational biology is the application of biological research into a useful invention, for example, a microbe that is capable of catabolizing waste products. In contrast, translational medicine specifically focuses on creating clinically useful products or procedures, irrespective of the source research, biological, physical, or social.

As a Science. Investigations can be divided into two categories that are relevant to translational research: basic and applied science. Basic studies seek fundamental knowledge, are nondirected, and are driven by curiosity and by a desire to understand a physical or biological system. The fundamental knowledge generated is an end unto itself. In contrast, applied research is a focused and targeted effort that seeks a specific goal, a solution to a problem.

The terminology can be confusing in biological and medical studies, especially those impacting patients and the clinic, because the concepts are often used erroneously"basic" for laboratory work and "applied" for clinical studies, with translation being a unidirectional arrow from bench to bedside. However, these descriptions misuse the fundamental 


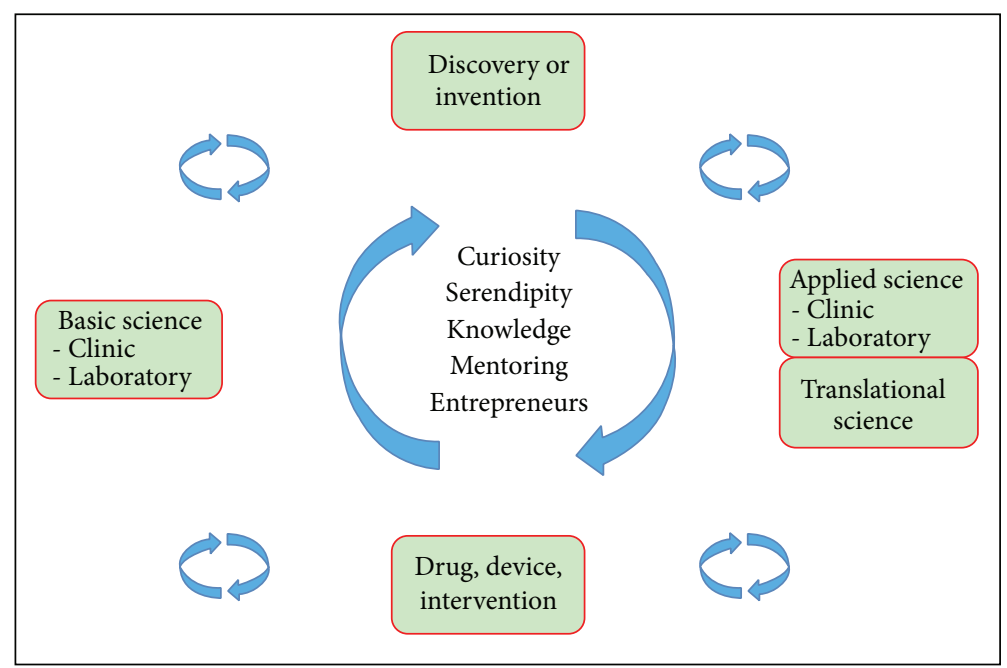

FIGURE 1: Virtuous Cycle. An iterative process that produces new knowledge, biological applications, and medical interventions.

meaning of the terminology and lead to a poor understanding of the iterations that occur during the process.

Accurate descriptions are as follows:

(i) basic science in the laboratory-seeks fundamental knowledge about physical or biological processes;

(ii) applied science in the laboratory-studies directed toward a specific utility;

(iii) basic science in the clinic-seeks fundamental knowledge on human pathophysiology;

(iv) applied science in the clinic-development of a medical intervention.

When used correctly, the terminology points to translational research as a highly interactive process, with a flow of information in multiple directions-a concept one can think of as a virtuous cycle, illustrated in Figure 1.

As an Analyst or Inventor. Further overlaid atop the definitions of translational research and peripherally related to definitions of basic and applied science is the methodology that investigators use to advance their work-analyst and inventor are good terms to use.

An analyst examines the mechanistic basis of a particular phenomenon, for example, the molecular elements that control bacterial cell growth or the underlying principles of a medical device. Using a reductionist approach, the analyst examines the physical and molecular mechanisms through hypothesis generation, experimental testing, and then validation or revision based on empirical results. Although the process may involve adaptation of a technology to further objectives, the primary focus is on probing and understanding the unknown. The subject matter is highly focused and the analyst knows "a lot about a little"; in fact, they know more about the molecular phenomenon or device than anyone ever, an impressive feat.

In contrast, inventors know "a little about a lot" and their goal is to create something new - to mix, match, and assemble various bits and pieces of what they know into something never before seen-more like an artist than an analyst. For example, instead of examining the molecular mechanism of bacterial growth, an inventor may use a blank canvas and their knowledge of bioengineering, optics, cell biology, genomics, and microscopy to create a novel imaging system-a new technology that reveals insight into DNA conformational states that mediate cell division, an impressive feat of a different sort, one that will open up whole new avenues of investigation for the analysts.

In the real world, the virtuous cycle illustrated in Figure 1 is an exciting, difficult, stop-and-start process comprised of a mix of different types of translational research processes, different types of basic and applied science, and different types of analytic and inventive researchers, with an amalgam of hybrid forms and many shades of gray.

Hidden within this whirlwind is the most important aspect, the one that begs the critical question vis-à-vis the virtuous cycle-how can the system be improved?

\section{Historical Perspective}

Although translational research is sometimes portrayed as a relatively new concept, initially coined in the 1980s, the process has in fact been practiced for millennia. Early examples exist in agriculture and in training of animals for domestic purposes. Loosely applied, any effort to improve the human condition based on new scientific knowledge can be considered translational: breeding of crops, use of fertilizers, and development of crude pesticides. Moreover, outside of biology and medicine, the translation of new knowledge in physics and electrical engineering into siliconbased devices over the past half-century has been nothing short of spectacular, world-changing to be sure. At present, though, the most popular use of the term "translational research" refers specifically to work within the biomedical research community. 




Figure 2: Insulin. Steps in the understanding of pancreatic islets and insulin biochemistry, and subsequent clinical treatment of diabetes.

Alexander Fleming's notable discovery of the Penicillium mold in 1928, followed by discovery of techniques to extract the antibiotic for treatment of bacterial infections, is a classic example of translational medicine, highlighting the tremendous upside of the process $[27,28]$. Similarly, the discovery of insulin and its use in treating diabetes is a remarkable achievement of the 19th and 20th centuries, with the major advances shown in a timeline in Figure $2[29,30]$.

From both scientific and clinical perspectives, the insulin story represents 150 years of stunning progress, basic investigation of anatomy and physiology, specifically the pancreas and Islets of Langerhans; early treatment of diabetic patients with relatively crude extract forms of the hormone; and then utilization of new laboratory techniques in molecular biology for in vitro production of biosynthetic insulin, including novel analogue forms with clinically useful activity such as rapid onset and increased serum half-life [31-34].

Prior to the use of insulin in the 1920s, diabetes was a near death sentence for patients. The disease was associated with high levels of morbidity and mortality and was particularly cruel in the way it affected children. The discovery and medical application of insulin altered forever the fate of those affected by the illness, followed by successive waves of improved benefit as basic and applied science pushed the frontiers of knowledge, continually making the disease easier to manage and life better for patients [35-38].

The commercial production of biosynthetic insulin by Genentech in the 1970s was a watershed event, for all intents and purposes marking the dawn of the modern biotechnology industry, a key inflection point. The effect on applied science and economic activity cannot be overstated as this commercial success engendered both interest and confidence in the burgeoning industry, an enterprise that now does tremendous good in society [39] (see Appendix). The insulin pioneers blazed an exciting and important new trail, showing what was possible in the field of translational research and biotechnology.

The insulin story also highlights the important historical role of societal investment in science, including philanthropic support, government funding, involvement of academic institutions, and R\&D efforts in pharmaceutical and biotechnology companies [40-47]. Without this robust and flourishing ecosystem all the societal good that resulted from discovering and utilizing insulin would have happened more slowly, or perhaps not at all.

Besides antibiotics and insulin, there are many translational medicine success stories over the past century. These advances range from progress in understanding and managing cardiovascular disease, to improvements in cancer therapies, particularly for childhood leukemia, to advances in treating psychiatric illnesses. A particularly exciting cutting edge area is synthetic biology, integration of genomic data sets, molecular biology, and new synthesis tools to design organisms with novel functions [48-71]. The potential applications here are almost endless; organisms as laboratory tools for basic research, bacteria useful in cleanup of petroleum spills, new vaccine production methods, and defining the critical gene set necessary for independent life. As with other genomic areas of research, synthetic biology carries with it a degree of risk; thus there is an important need for regulatory oversight [72-78]. In the context of the virtuous cycle, such supervision needs to mitigate potential hazards without becoming excessive or stultifying.

Today, many projects are influenced by advances occurring in basic and applied genomics, undergirded by rapid technological improvements in DNA sequencing that enable 
a wide spectrum of new research avenues, economic development, and clinical applications [79-89]. If ever a case needs to be made for the societal value of translational research, genomics is an on-going success story par excellence $[76,90-$ 106].

In each historical example one can see manifestation of the important principles embodied in the virtuous cycle, scientific curiosity, chance discoveries and serendipity, targeted goals, successful products and procedures, and continued knowledge generation and product improvement; spin the cycle again. Additional noteworthy elements based on past history include free and unfettered scientific inquiry with an emphasis on bottom-up investigator-initiated studies, information flow through a peer-reviewed publication process, training and mentoring of young investigators as a cultural norm and expectation of senior researchers, and an entrepreneurial culture that rewards risk-taking and productivity.

New Tools. Important translational elements created over the past few decades include a spectrum of educational programs, conferences, journals, organizations, academic societies, and analytic tools for measuring cost and effectiveness-all parts of a system that nurtures growth of new ideas [107-119]. For example, scientific journals in this space now include the following:

Science Translational Medicine-http://stm.sciencemag.org/;

Journal of Translational Medicine-http://www.translational-medicine.com/;

Translational Research-http://www.translationalres. $\operatorname{com} /$;

American Journal of Translational Research-http:// ajtr.org/;

Translational Medicine-http://www.omicsonline. org/translational-medicine.php;

Clinical and Translational Gastroenterology—http:// www.nature.com/ctg/index.html;

Clinical and Translational Medicine-http://www. clintransmed.com/;

Clinical and Translational Science-http://onlinelibrary.wiley.com/journal/10.1111/(ISSN)1752-8062.

In the United States, two historical developments that moved the field forward were the Bayh-Dole act passed by the US Congress in 1980 and establishment of offices of technology transfer at universities and medical centers [120, 121]. Together, the new law and administrative structures are a mechanism for commercializing government-supported discoveries, with a positive effect on the translational landscape and economy. At present, the primary debate around the Bayh-Dole act is efficiency and, namely, determining if the law as written and the current methods employed by technology transfer offices are optimal [122-127].

\section{Challenges and Conjecture}

So, based on historical successes in the field of translational research and the current exciting advances that are occurring in genomics, synthetic biology, and in other areas, what is the problem? Why does the title of this article end with (or Not)?

Actually, there are many problems.

The aim here is not to be overly critical or negative, nor is it to miss the wonderful advances that are occurring by focusing too much on the shortcomings of translational research as it is practiced today. All steps forward in this space should be recognized and celebrated, and society is wise to build upon these accomplishments. Moreover, when one scans the translational landscape it is evident that there are many pockets of excellence, where success outweighs failure and development of new concepts triumphs the difficulties.

However, that being said, there is much anecdotal and objective evidence to suggest the enterprise is not operating at full speed, due both to inherent challenges in the process and to a set of problems that are self-induced $[3,4,7,11-16,18,110]$.

Eight distinct yet overlapping areas in need of assessment are listed below. This set of issues is not exhaustive, of course, and there are additional elements that should be explored further, the relationship between academia and industry as a prime example. However, the topics listed below touch on many of the key difficulties in translational research as it is practiced today:

(i) integration (silo problem);

(ii) model systems;

(iii) data reproducibility;

(iv) distributed power;

(v) mission;

(vi) clinical research;

(vii) bureaucracy;

(viii) selection of investigators.

Acknowledgment of the inefficiencies in translational research is heard not just among those involved in science and medicine, but across the spectrum of society, including the business community and popular press (see Appendix). An article in Newsweek in 2010 illustrates the debate occurring in public forums, accurately describing many of the frustrations with the process amongst funders and patient advocacy groups. Similarly, two 2013 articles in Time Magazine covered the Stand Up to Cancer (SU2C) program that originated in the entertainment industry, highlighting similar dissatisfactions. As the primary beneficiaries of the fruits of scientific inquiry, the public is rightly interested in this matter and wise to be concerned with how translation is practiced.

When evaluating inefficiencies within the translational research system, it is important to be cognizant of the difficulties associated with turning new knowledge into useful societal benefit. The task is not easy and the process almost never occurs simply or with a perfectly uphill progression 
slope. To make this point more strongly, consider the development of silicon-based technologies (electronics, computers) as opposed to the biotechnology field. One observes a marked contrast between the two. Whereas the basic substrates and building materials for electronics are relatively well understood and behaved, not to mention nonliving, carbon-based life forms remain mysterious in many respects and the capacity to design and control them is limited. The amount of information and high-level regulatory control is considerable, rendering the task of transducing biological knowledge daunting.

A major inflection point in the electronics and computer industries was the invention of solid-state transistors at Bell Laboratories in the mid 1900s, greatly increasing the capabilities of logic-based circuits; electronic design on a new scale became possible leading to rapid improvements in manufacturing, notably the development of integrated circuits and an explosion in devices, applications, and computing power-the virtuous cycle went into overdrive [128-130].

In contrast, the design and manufacture of carbon-based systems, although underway and successful to some extent, insulin production as an example, has not yet come to fruition in a manner analogous to electronics. In fact, one may argue that many advances have been more fortuitous than rationally designed, hijacking nature's strategies in order to accomplish specific and limited goals. This situation may be changing now, with new synthetic biology tools perhaps analogous to invention of the solid-state transistor, although one must be cautious about over promising in this space until more substantive progress is made.

The key point, given the biological challenges, is to again highlight the absolute need for a maximally efficient and supportive translational ecosystem. Here, good enough is not good enough; business as usual will not suffice and a sense of urgency is needed; inefficiencies must be recognized and then mitigated or eliminated-much in human health depends on getting this right.

Looking forward, the crucial question is how could the translational system specifically be improved? How could successes be built upon while at the same time minimizing elements that lead to failure?

One imagines there will be many "correct ways" to translate biological and medical knowledge to the public, depending on the specific circumstances and health care issues involved. Diversity and experimentation are good things - one size does not fit all. Therefore, instead of focusing on specific organizational structures or institutional hierarchies that might be useful in the future, it is better to examine general principles and speculate on how they might be experimented with and improved upon.

Importantly, the future design of translational research systems needs to be developed with young investigators firmly in mind. Their drive to succeed will be based on achieving specific goals-satisfy curiosity, produce new knowledge, engender societal good, personal financial benefit, entrepreneurial satisfaction, contribution to society's economic development, and inventors' pride. Additionally, many of them will desire to be part of something bigger, part of an exciting environment they are proud to be associated with, a cool brand if you will. Tomorrow's leaders need to carefully consider what their organization stands for, how it operates, and why bright young folks would want to be involved.

Integration (Silo Problem). When one asks investigators about challenges in translating new research advances into applications, a frequent complaint is the difficulty in traversing the various components of the system, disciplines and subdisciplines in academia, the laboratory, the clinic, and the public and private sectors, the so-called silo problem.

Certainly, there are many positive aspects emanating from scientific and medical subcultures; silos are not all bad. However, when the biological or clinical problem at hand requires a multidisciplinary approach or requires the synergy of more than one discipline, the translational system begins to show its weakness-instead of whirring along productively, the virtuous cycle becomes slow and ossified.

An organization or department populated by researchers from within a scientific or medical discipline provides a comfortable group with whom to discuss ideas, share excitement about new advances, obtain technical advice, and commiserate together when projects go badly. Moreover, congregation of like-minded investigators around a focused mission helps to promote productive specialization and a high degree of expertise in many fields, a process essential in moving science and business forward.

In contrast, congregation of unlike-minded investigators from across disciplines stretches everyone's understanding of science and medicine, provides different sorts of thinking and problem solving skills, and exposes investigators to materials and technological capabilities of which they were unaware. Such arrangements also promote work "at the edges," areas where subtypes of science and medicine overlap, a historically difficult yet exciting and often productive cauldron. Moreover, this environment provides ready access to theoretical and technical feedback, offering early-stage reality checks on ideas that transcend an individual's expertise-does this make sense?

Both organizational structures have value, although the more usual is the former not the latter. Looking ahead, though, institutional environments need to be questioned more deeply. Is it better to create a new university or company department organized around a particular theme or discipline, physiology or cancer biology for example? Or is it better to build multidisciplinary departments and units-a biochemist, a physicist, a clinician, an engineer, a social worker, and a business expert? Would this be a more productive arrangement than a theme-centric department or division in academia or industry? Would this approach spin ideas more rapidly and efficiently through the iterative virtuous cycle, with input coming from multiple perspectives?

One does see examples across the research community showing progress in this regard, at least to some extent. The establishment of Clinical and Translational Research Centers at institutions across the US represents recognition of the need for multidisciplinary environments that support the scientific activities and career development of translational researchers $[115,131]$. However, these resources are typically 
provided atop a well-established silo system, as an attempt to counteract compartmentalization, so impact is somewhat limited.

Looking ahead, nonsilo, multidisciplinary organizational structures built de novo from the ground up may be necessary to make progress on many diseases and is an area for future innovation. Although such environments likely will play a key role moving forward, one needs to be careful not to throw out the baby with the bathwater. Individuals pursuing their own ideas and passions will always be the lifeblood of successful investigation. Science by committee or by forced collaboration is rarely successful. A particular concern when designing an integrative environment is when a leader is selected based on success in a traditional silo, Chairman of Biochemistry, for example, who then requires researchers to follow those specific cultural practices, square pegs into round holes; this is a recipe for slow progress if not surefire failure. Big-tent leaders and big-tent environments will be essential.

One way to encourage multi-investigator activities is to establish incentive programs that reward these efforts, understanding there is a natural inertia to "leaving the laboratory." There are many ways to accomplish this goal, for example, a royalty-based payment structure, somewhat similar to profitsharing mechanisms used by many corporate concerns. In this scenario, a defined percentage of commercialization income is dispersed to everyone in a department as a reward for participating in an interactive and collegial environment. In other words, at least to a degree, "your success is my success and vice-versa." If an investigator has a commercial triumph it benefits all, producing income and funds to support infrastructure and training, thereby incentivizing efforts to help colleagues and mentor young researchersone never knows when and how such efforts will pay off-a method to lubricate the virtuous cycle.

In contrast to oiling the cycle, there is one aspect of the silo problem within academia that stands out as particularly pernicious, a concept akin to pouring molasses onto the virtuous cycle. Many in the research community agree the issue is particularly problematic and needs to be resolved, and sooner rather than later. Others are harsher in their assessment-worst idea ever.

The concept is that an individual investigator can be either a basic scientist or an applied scientist, but never both-each person must stay in one silo or the other.

An ingrained cultural academic credo accompanies this sort of thinking, often proclaimed loudly and in an authoritarian tone; "Everyone knows that basic scientists are highly superior to applied scientists since they are pure, noble, and unencumbered by the grubbiness of commercialization."

What follows naturally is that doing applied science somehow lessens one's ability as a basic researcher and that less knowledge and breadth of experience is preferable to more. A hyperfocus on one's primary scientific interest within a silo is said to be the only way to succeed. Never mind that the actual evidence is contradictory to this assertion, as investigators who are the most entrepreneurial remain productive with respect to basic science, produce large numbers of high-quality scientific publications, and are often the "superstars" of their fields [132-135]. And never mind that even the most theoretical of academic scientists and mathematicians typically participate in a wide range of activities: teaching, mentoring, fundraising, grant writing, and departmental faculty matters to name a few. Participating in applied science and commercialization at modest level, or even as a consultant, is considered disqualifying by many, rendering one impure, on the dark side, and no longer capable of performing high-quality basic science.

A common accompaniment to this notion is that commercialization induces scientific bias due to financial incentives, a charge that is not necessarily supported by published studies on the influence of industry funding [136]. And what of the other biases that exist in academia? Obtaining grants, being promoted, attaining tenure, publishing manuscripts, and personal recognition are all potential bias-inducing reward mechanisms. These too should be disqualifying based on the logic of the silo system. Clearly, conflicts of interest across a broad spectrum of activities are simply part and parcel of biomedical research. The remedy is not to shut down the system or abdicate the responsibility of helping patients and the public. Rather, the remedy is transparency, responsible oversight, and well-defined guidelines, features that should be emphasized in all translational organizations, especially when studies touch upon the clinic.

To the uninitiated, the silo problem may appear as an amusing and somewhat silly aspect of human nature within the scientific community that researchers like to encase themselves into a silo and tell everyone who will listen why their particular discipline is better than others. But to the initiated this is a grave problem. Self-imposed compartmentalization. A highly ingrained, dogmatic, and cultural ethos passed down from generation to generation-stay in your silo, all other work is inferior, and commercialization is uncouth to boot.

The outcome of this basic versus applied mentality, the insidious aspect, is that commercial and clinical applications become "someone else's problem." For many academics, simply doing basic research, generating knowledge, and publishing manuscripts is sufficient. Their day is done.

But consider the effect of this scenario on the virtuous cycle. The people who best know the intricacies of a particular line of scientific inquiry - the creators, the discoverers, and the inventors - the key holders of information, both theoretical and experiential, remain on the sidelines and do not participate significantly in moving their work to patients and the public, based on a premise that is patently untrue, that human beings cannot multitask.

From a first-principles engineering viewpoint, could there be a worse design flaw in today's translational system?

The role of the most important element in the virtuous cycle, the creative individual scientist, the key driver of progress, is artificially diminished-their energy, drive, knowledge, and expertise dissipate away-and it is someone else's problem.

In the future, however, this will not be someone else's problem. It will be firmly the problem of tomorrow's translational leaders, and a high priority at that. 
Model Systems. The history of science is replete with successful use of models. From early astronomy to quantum physics to understanding DNA structure, employing these systems to understand and predict physical phenomenon was and continues to be essential in science. In modern translational research, models provide experimental templates for making observations and testing hypotheses in the laboratory, an essential role given the complexity of biological systems and the ethical limits associated with clinical studies involving humans [137-145].

Each of the many models employed in biological and medical research has its own strengths, weaknesses, and caveats; thus it is important not to overgeneralize and reach conclusions that are too broad [146]. However, it is also important to critically examine these systems, since so much of what comes next in translational research depends on them.

A particularly illustrative example that highlights both the value and the problems with models is the widespread adoption and use of in vitro cell cultures in biomedical research over the past several decades. Cells grown in the laboratory are advantageous in many respects since they enable a wide variety of molecular and mechanistic studies, are readily available, mimic biological phenomena, are inexpensive to obtain and maintain, and can be manipulated using molecular biology techniques to facilitate both basic and applied research.

Cultured cell lines are particularly useful for mechanistic studies of individual molecules and specific biological processes. For example, they were essential in understanding the signaling mechanism and information flow that transduces external stimuli into events in the cell nucleus, such as altered mRNA transcription or DNA synthesis. In the laboratory, a model-centric, reductionist approach uncovered a remarkable stochastic cascade of events and elucidated the function of key proteins, how they are activated and inactivated, how they are regulated, and how they interact with each other. Moreover, study of cell types exhibiting varied and contradictory behaviors in response to external stimuli was useful in teasing out subtleties in molecular mechanisms. This basic information, detached from any useful application or medical intervention, represents human scientific inquiry at its finest-curiosity, discovery, hypothesis generation and testing, and ultimately new knowledge.

There are no complaints here.

The problem with cell culture models manifests itself at the second stage of inquiry, after the initial experiments in the laboratory are complete, when one asks more questionshow do these models relate to biological phenomenon on a larger scale, at the tissue, organ, organism, or disease level? What aspects are relevant to the system being modeled, often the patient, and which are not? Which findings represent true biological knowledge about how a molecule or process functions in nature?

Alternatively, which findings are not real but are due to cells growing in an abnormal environment, plastic flasks, and thus mostly irrelevant to real-world biology and to the patient? Because an event can occur in an artificial culture system does not mean that it is important or that it occurs naturally.

So, what is the wheat and what is the chaff?

Here the translational system breaks down in an important and some would argue deleterious way-the virtuous cycle deconstructs, but more ominously, can mislead.

An old joke often told by university professors on the first day of class is "Half of what you are going to learn is either wrong or woefully incomplete. The problem is that I do not know which $50 \%$ that is."

When used to model a larger biological phenomenon, beyond a focused molecular event, in isolation, the same goes for cell lines studied in the laboratory.

Notably, cultured cell models fit well into a silo-based research enterprise. This is both good and bad. On the one hand investigators never need to leave the laboratory to initiate and perform experiments, analyze data, publish papers, or advance a career-the messy business of traversing different scientific and medical disciplines is a nonissue. Inside the laboratory, the basic science-discovery aspect of the virtuous cycle hums along. On the other hand, though, the productive business of integrating multiple perspectives to understand models in their true context often does not occur-a major sin of omission.

However, the problem is worse yet.

Anyone working with cultured cells quickly learns it is possible to manipulate experimental conditions to generate varied, even contradictory results $v i s-\grave{a}-v i s$ a particular molecule or phenomenon, by changing the growth conditions or by selectively focusing on one particular cell line from the hundreds that are available. Inside the laboratory this is not problematic and is in fact helpful. Cells with different and opposing behaviors are scientifically useful since investigators can examine mechanistic events from multiple angles, irrespective of the relevance to the real world.

But the applied science phase becomes even more difficult now due to this explosion of new information [147, 148]. Which of the myriad publications and data sets on a given topic are correct and worth pursuing? Which of the studies from academia and from early preclinical studies in industry are based on an accurate cell line model? Which findings are relevant to disease in patients?

Nobody knows for certain.

If the biological work using in vitro cultures over the past 50 years had focused only on the basic science aspect, fundamental knowledge as the sole aim, then concerns about the validity of the data produced would be minimal; new biological and mechanistic knowledge would be sufficient unto itself. However, this is not the case. Investigators have and continue to employ cultured cells as ostensibly accurate models of physiology and disease, true representations of pathobiology. They are used for drug screening to assess the effects of potential therapeutic compounds on normal and tumor cells; they are employed to advance basic science studies of physiology, to learn how and why a process occurs; and, they are utilized to identify new drug targets based on differences in expression patterns in normal and diseased cells. 


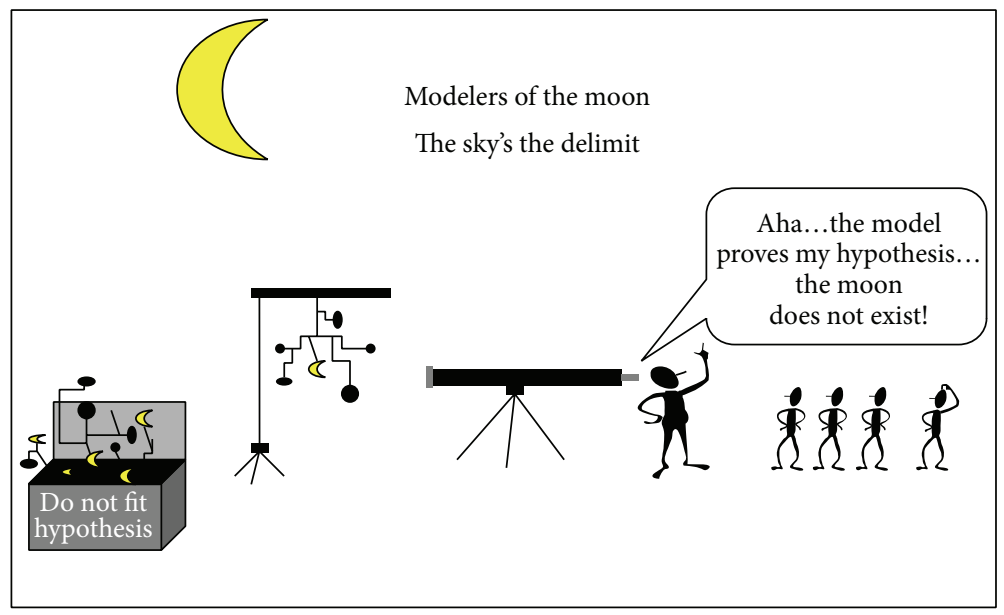

Figure 3: Models. Cultured cell lines as research models have both upsides and downsides.

If the cultured cell models are wrong then the whole enterprise collapses. The virtuous cycle does not just slow down or stop, what occurs is more troubling - the virtuous cycle spins furiously but misleads relentlessly. Some, most, or all the applied science that comes next is based on faulty premises, as shown in a tongue-in-cheek cartoon in Figure 3.

A recent article by Gillet and colleagues examined this issue in detail, reviewing the relevance of cultured cells as representations of cancer [149]. The authors could point to several scientific and clinical successes based on use of in vitro lines; however, their overall conclusion was that the limitations of the models are real and substantial, and thus they argued for development of new, more reliable, and accurate systems.

Other investigators remain supportive of current cell line models, noting, for example, that genetic and epigenetic changes often mimic what is seen in primary tumors in patients, indicating the lines are accurate at the DNA level $[150,151]$. Additionally, there are examples where cultured cell lines have indeed been useful as early-stage screening reagents, testing for therapies against single gene perturbations (as opposed to pathways) as one example [152]. Finally, other investigators rightly argue that new and improved cell line models show promise in mitigating some of the current deficiencies, for example, using three-dimensional culture systems, or performing drug screening with larger sets of lines to incorporate the full scope of heterogeneity seen in patients [153].

Certainly, the issues involving proper integration of cell line models in biomedical research are complex, and simplistic, overarching conclusions do not properly recognize the challenges involved or the state of the field at a given time in history. Moreover, it is important to keep in mind that no strategy is perfect; investigators working to understand human biology and disease need to start somewhere. Nonetheless, many strident critics are not forgiving - they say use of these models in isolation, in laboratory silos, has been largely unhelpful, confounding a generation of investigators in the fight against human diseases, particularly with respect to discovering efficacious therapeutic agents.
One must wonder if the perceived problem with cell lines would have developed to such an extent if biomedical research were populated with multidisciplinary teams rather than silos. Would the clinician in the group have immediately and critically questioned the relevance of a system meant to mimic a disease process for drug screening purposes? Would the gold standard, the patient or data derived from the patient, be involved at the outset of a project rather than years later after extensive funds were spent on basic research and clinical trials only to find the model was misleading?

More importantly, will the biomedical research enterprise more fully integrate and synthesize the information being generated by new genetically engineered mouse models arriving on the scene today? There are several hopeful signs suggesting that this will happen. Development of new resources for comparative pathology to assess similarities and differences between mouse models and humans is promising. Additionally, refinement of methods for tissue banking and creation of sources of patient and murine organs are becoming increasingly useful for integrating laboratory findings with patients and diseases. Encouragingly, the value of several different mouse models is already evident [154156]. As a specific example, if the insulin timeline in Figure 2 were extended to today, one would see additional successes based on use of the ob/ob and other mouse models to better understand metabolism, appetite, and obesity [157-175].

Data Reproducibility. A more recently recognized challenge for translational research is a lack of reproducibility of a surprisingly large percentage of basic science results generated in academic and commercial laboratories [176-183].

At one level, nonreproducibility and lack of scalability of novel research findings is expected and is an important part of the scientific process; risk-taking, daring established scientific and medical dogma, and contrarian thinking are the lifeblood of the enterprise, leading inevitably to some false leads, incorrect notions, and failures nestled amongst the successes and legitimate leaps forward [184]. Everyone in science understands that many new developments, irrespective of their initial promise, will not succeed when tested on 
a larger scale or when placed under more rigorous scrutiny. And this is fine-a raucous, bubbling, risk-taking scientific ecosystem is a good thing, and failure is to be expected when difficult tasks are undertaken.

Yet, the high level of irreproducibility of laboratory discoveries is troubling [185]. Moreover, many of these studies were not simply early stage provocative findings but were ostensibly more advanced and certain results. The explanation for this nonreproducibility is speculative and there may be many elements involved. However, since successful translation obviously depends upon the accuracy of these early studies, the community is wise to be concerned with and examine this newly recognized problem in detail [186].

Distributed Power. A hallmark underlying almost all of the wonderful advances in science from the Renaissance forward is researchers pursuing their curiosity and interests in an investigator-initiated fashion-free to think, conjecture, experiment, publish, and commercialize, even when their ideas are contrarian, in fact, especially when their ideas are contrarian.

That is not to say that there is not a role for big science or big business, there is. The National Aeronautics and Space Association in the US, the International Human Genome Project, and Apple Inc. are all good examples, to name just a few. But even here, the underlying science and technology on which these organizations are built, the real creative leaps, are typically produced by individuals working on their own or in small teams, not in large top-down assemblies.

Today, most institutions, especially in academia, are effective in establishing structures to support investigatorinitiated basic research efforts, producing a wide array of small laboratories. These "Mom and Pop shops" operate in an open and free environment with a laissez-faire philosophy towards science. If you can fund it, you can do it. The researchers pursue their creative ideas and work in whatever fashion they choose. In some ways, one can consider them to be "academic entrepreneurs," quintessential small business stewards of a sort.

In contrast, institutions are generally not as good in supporting the applied science phase of translation, due in part to the silo and cultural issues described above, as well as a tendency to assert control at this stage, often in a negative way, whether it is an academic center, business concern, or government entity. Specific manifestations include topdown control of licensing and project direction, arbitrary restrictions on involvement of investigators in commercialization, poorly conceived academic incentive structures that reward basic science achievements (academic publications) over applied science successes (allowed patents or license agreements), and an over-focus on short-term institutional goals rather than fostering the long-term unbridled creativity and ingenuity of investigators.

Like the internal cultural restraints on applied science and commercialization that exist in academia-that it is someone else's problem-institutions frequently displace or minimize the role of creators in the translational process based on external rules and regulations.

But is this wise?
Given the complexities, risk, and difficulties of translating knowledge into public benefit, perhaps it should be the investigators who are central decision-makers guiding this second stage of translation, the applied phase. They are the ones who discovered or invented the "something new." They are the ones who will walk through walls to make things happen when given a chance, encouraged, and not encumbered by artificial cultural limitations or institutional policy. They are the ones who will take risks that nobody else will consider. They are the ones who will go full steam ahead when other scientists, technology transfer offices, corporate leaders, investors, and business folks all consider success unlikely and their ideas maybe even a little daft. And they are the ones who are ideally positioned to integrate the basic science and applied science silos, short-term and long-term. Their role in the process is essential, yet they are often only minimally involved in translation.

It is not that the inventors and discovers need to do everything hands-on-they do not need to govern or micromanage every project or commercial spinoff. What they do need to do, however, is direct the overall effort and strategy. They need to survey the laboratory, commercial, and healthcare landscape and assess what needs to be done with their finding, committing to making things happen for the benefit of themselves, their organization, and society. They are the key holders of the creative juice and technical knowhow, the intellectual drivers of the inquiry and its potential applications, and should be highly involved in the process, not relegated to the sidelines.

Looking ahead, it likely will be beneficial to more fully empower the creators-the discoverers and inventors. To enable this change, however, institutional power will need to be distributed and dispersed, from administrators and managers to the creative agents. Unfortunately, such a transfer of power is antithetical to most university, government, and corporate leaders, whose goal is usually to amass and then preserve power at all costs, including accepting a loss of translational efficiency to maintain control.

Society will need to select its next generation of translational leaders wisely. Much depends on getting this (them) right.

Mission. In addition to distributing power to an institution's discovers and inventors, another area ripe for innovation is for an individual-centric mission in place of centralized one.

Today, the undertaking of most institutions or their substructures, a department in a university or a division within a pharmaceutical company, is typically centered on a specific discipline or product-The Department of Molecular Biology, or Stem Cell Therapies, Inc. This is fine, of course, and a necessary division of labor in many organizations. And certainly from a historical perspective such focus made sense for efficiency as the agencies of society were simply trying to promote a decent standard of living for its members; there was little chance for pondering business practices and experimenting with new methods; conditions were too harsh.

However, these societal developments, occurring over several centuries, also created extensive sets of dogmatic rules and ingrained practices that sometimes retard today's 
translational efforts and often go unquestioned and unanalyzed. Society now has more freedom to assess methodologies, which is especially important in translational research where progress is often slowed by orthodoxy.

An alternative to the classic organizational-centric mission is an individual-centric one. Instead of an expectation of coalescence around a central focus area or product, the goal of the institution would be of a different sort, to embrace and enable the entirety of creative abilities and instincts of investigators. Rather than researchers working only on one scientific discipline, task, or product, while at the same time subjugating other creative ideas or pursing them just as part-time, outside hobbies, an inefficient use of creative brainpower, a future mission statement of a translational organization might be:

\section{Support investigators in being maximally creative and productive over their vocational life, embrac- ing the pursuit of all talents and interests.}

The statement emphasizes overall human potential rather than a single goal or single research area, loosening restrictive remnants and counteracting the silos and cultures that discourage progress. The emphasis shifts from what the institution needs and wants to what the individual needs and wants. In parallel with breaking down silos and distributing power to investigators, an individual-centric mission would go another step further by encouraging pursuit of a multiplicity of ideas and interests, including across a broad range of topics and disciplines, presuming investigators will continually explore new career directions and ambitions. The hyperfocused approach of the past, "You are an X and you will only pursue Y-type studies," will be deemphasized. Instead, an individual-centric mission would support the undertaking of many creative projects, of very different sorts, with the overarching goal that every idea, insight, passion, and potential innovation in the minds of an organization's workforce is tested and evaluated, with nothing left on the shelf.

One sees this sort of arrangement at a modest level in some organizations today; however, increasingly radical structures that embrace maximizing investigator creativity as a core mission is an area ripe for innovation in the academic, government, and private sectors. Certainly, great progress emanates from those who spend their lives working on a single topic. But this myopia can be bad, too, and science is replete with examples of fundamental advances generated by newcomers to a field, by outsiders who cross into new fields to view problems with a unique perspective, old problems seen with fresh eyes. The public and patients may benefit greatly in the future by such an evolution in institutional mission focus, in ways that are unpredicted and unexpected.

Clinical Research. A major impediment to translational medicine that deserves brief mention is the laboratory-clinic interface, a challenging physical and cultural dichotomy that is notoriously difficult to traverse-a unique incarnation of the silo problem. In the medical research arena, it is common to hear investigators on both sides of the divide decry the difficulties working across this boundary. The sins of omission here are numerous and disheartening.

An organization that was specifically designed to bridge the laboratory-clinic gap is the intramural program of the National Institutes of Health (NIH) in Bethesda, Maryland. Recognizing that interaction at this interface was crucially important to progress and that proximity matters in this regard, the NIH constructed a unique medical research hospital in the 1950s to integrate science and medicine, localizing the laboratories literally across the hall from patient rooms. To advance translational goals, clinical scientists who could navigate both the laboratory and clinic were recruited-one person with two perspectives, generating unique insights into the basic pathophysiology of disease as well as associated medical interventions, as much a bedside-to-bench strategy than the usual process of starting in the laboratory and moving towards the patient [187].

The outcome of the NIH strategy was quite amazing, including new chemotherapeutic and immune system-based treatments of malignancies, advances in surgical and medical management of cardiac diseases, studies on insulin and metabolic disorders, long-term efforts to describe the natural history of rare illnesses, and a deeper understanding of the pathogenesis of HIV and AIDS, with development of an assay to monitor the blood supply and protect the public [188].

Perhaps as important as the scientific and medical accomplishments of the NIH program was the training of young physician-scientists and formation of a career path for them, producing a cadre of distinguished investigators who went on to establish and populate many academic research centers in the US and worldwide, accomplishing much and in turn training the next generation of clinical scientists [189].

The lesson exemplified by the NIH Clinical Center is that surmounting barriers in translational research, in this case translational medicine, does not happen automatically nor easily; rather, it takes vision, courage, and a sustained commitment [190]. In the 1950s there was significant resistance to the idea of a government-sponsored research hospital and the success of the endeavor was not assured. Yet the pioneers persisted, did the experiment, and won the day.

Bureaucracy. Everyone who has dealt with a large organization understands the pitfalls of bureaucracy. Oftentimes, it becomes an on-going butt of jokes, or an eye-rolling acknowledgement amongst workers of the seemingly endless problems created by rules, regulations, disparate offices, and paperwork.

Many people who work for or interact with bureaucracies become resigned to their destructive inefficiency, engendering a Stockholm syndrome-like effect where the unacceptable becomes acceptable and the intolerable tolerable. Of course, there is a terrible price to be paid for this state of affairs; progress is slowed dramatically, initiative is discouraged (too difficult, too risky), and responsibility is nowhere to be seen (problems are someone else's fault).

For translational research, bureaucracy is not just another hurdle to overcome, but often a death knell that suffocates ongoing projects or discourages work from being started in the first place. The inherent multidisciplinary, multidepartment 
nature of translation exposes the process to onerous bureaucracies and subbureaucracies, large and small, amplifying the problem greatly. It is difficult to put metrics on the damage that bureaucracies cause in this space, especially the "might have been" successes that do not occur. But anecdotally, many in the translational and clinical research fields would rate the effect of bureaucracy as somewhere between catastrophic and ultracatastrophic.

When bureaucracy slows translation of new knowledge into a nonclinical product, a biological widget of one sort or another, this is bad. But when bureaucracy slows, stops, or prevents translation of life-saving drugs or medical devices to patients and the public this is more than bad, it is wholly unacceptable.

Or at least one would think so. Yet bureaucracies live on happily today and continue to do great damage to translational research, with no end in sight. This is mystifying.

Bureaucracies develop and expand naturally as an organization grows in order to meet administrative burdens. Obviously, this is necessary and absence of such structure would lead to chaos and dysfunction. But bureaucracies grow independent of need, and much like weeds in a garden, become unruly and destructive. It is likely that the successful organizations of tomorrow will address the problem as a serious matter if for no other reason than to stay competitive. Actively designing procedures to monitor and eliminate dysfunctional bureaucracy wherever it exists, becoming hypervigilant on the issue, and continually scanning an organization for such inefficiencies will become essential.

One simple design strategy to mitigate the difficulty is the "adult-in-the-room" concept. As virtually everyone who has suffered through one sort of bureaucratic nightmare or another can attest, attempting to coordinate multiple administrative offices and administrators, each with separate procedures and all with an interest in maintaining their power base is exasperating and discouraging. Whereas distributed power for investigators is a good thing, distributed power for administrators is not. Translational science is difficult in the best of circumstance; add these concerns to the mix and productivity plummets. This is not a small problem.

In contrast, the translational experience is very different when there is a single person involved with the knowledge and administrative power to make rapid and informed decisions-an adult-in-the-room. Here, agonizing weeksand months-long administrative arguments and power disputes dissipate, decisions are made in a timely fashion, and the focus is on the legitimate scientific and medical challenges, not on artificial administrative ones. It is a night and day difference.

Tomorrow's leaders need to ask and answer two key questions as they design their new organizations and departments. When and where will bureaucratic inefficiency appear? And in all such situations, who will be the designated adultin-the-room? Although this solution may appear naïve or oversimplistic, many translational researchers in the trenches would argue that it is not and should be "institutional design principle \#1" moving forward.
Selection of Investigators. Issues around the process of selecting and promoting young investigators applies to every organization, academic and commercial, large and small, but is particularly acute for those that include translational research in their portfolio-this step must be done correctly due to the inherently challenging nature of the undertaking; all of the best minds are needed here.

There are two matters with which to be concernedrestrictive entry of young investigators and perpetuation of like-minded thinking.

The typical path to success in today's biomedical research system is for a student to join a productive laboratory with a prestigious mentor, be successful in their studies, follow the usual conventions in terms of general attitudes and research approach, and become part of an elite junior class favored to win one of the scant number of high-level jobs available in academia or industry. The young candidate is then chosen for an assistant professorship at a university or group leader in a company and given a relatively large start-up package of salary support, equipment, and other resources. Certainly, this is one successful method for producing young investigators who will go on to do great things.

However, science, medicine, and society are likely paying an enormous price for this insular system. Access to the jobs that permit independent thinking (professorships, group leaders in industry) is limited to a small minority of young investigators, at a career stage where it is difficult if not impossible to accurately predict success, and with a heavy bias towards investigators who think like their mentors. Most young people are shut out of the process, relegated to becoming support staff of one sort or another, and their chance to lead studies into new territories, pursue novel or unpopular lines of investigation, or actively push back against the dogma of the day are minimal or nonexistentthis is not good for science, translational or other. Moreover, the traditional method of career advancement inculcates investigators in the problems described earlier in this paper, for example, perpetuating silos and the myriad other cultural practices, overt and covert, that trouble efforts to move science from the laboratory to the public.

The good old boys network and now the good old girls network are quite effective at maintaining the usual order, but this occurs at great scientific and societal expense. Instead of an army of bright young investigators bursting onto the scene as Young Turks hell-bent on upsetting the status $q u o$ and knocking the powers-that-be off their pedestals, in other words pursuing science the way it should be done, the system produces early-stage investigators who are bright and accomplished to be sure, but also "members of the machine," focused on pleasing mentors, patrons, and tenure committees-a recipe for group-think success but radicalthink disaster.

Certainly, one should not decry or complain about the accomplishments of those who succeed in science and medicine today, and a democratic outcome is not what is needed, let the cream rise to the top. Rather, it is the limited opportunities and me-too thinking in place of a true meritocracy that are unhealthy and unwise. Better to let all the bright youngsters in, let them compete, and then let 
the marketplace of ideas, discoveries, inventions, and products determine the true visionaries and innovators.

Future leaders might consider a different sort of strategy for developing the next generation of talent. Rather than recruiting a single investigator with a large start-up package; five to ten of them could be hired from a broad range of sites, with a high degree of diversity, including less traditional thinkers. Each of them could be provided with a partial salary, a small research budget, a supportive environment of colleagues and collaborators, and access to a common laboratory for pilot experiments. And then let them develop their ideas, apply for funding, establish industry or academic collaborations, or start their own small companies. In other words, instead of selecting a few key individuals who come from the right places with the right attitudes, let as many young investigators into the system as possible, give them creative independence, and then let the process flow. The young scientist who is bursting at the seams to get started, who says, "All I need is a corner in the lab and a chance to test my ideas" is a good bet for success. Give more of them a chance, get out of their way, and see what happens.

What is especially disturbing about today's selection system is that the majority of young investigators, with their potentially earth-shattering ideas, are shut out at a time when they are most creative, most ambitious, most likely to take risks and push into novel scientific territories, and most able to exist on a small salary-they do not need much, just access and a chance to succeed. Individual institutions and society at large stand to benefit greatly by putting as many creative young folks as possible, as soon as possible, in charge of shaping and pushing science and medicine forward.

Today, there are some limited efforts to address this problem, the NIH pathway to independence award as one example (see Appendix). However, these programs offer only minimal changes. Looking ahead, no single problem is more important to address than access to the machine. Let all the young investigators in so they can test their ideas and determine the real winners-a true meritocracy.

\section{All Together Now}

Science does not know its debt to imagination. (Ralph Waldo Emerson)

Imagine a young Ph.D. investigator in the future who is hoping to study the biochemical basis of cell growth and then translate her findings into new therapeutics.

Will she be given a chance? Will she be allowed to enter the system? Will she be free to paint "outside the lines," to experiment with radical ideas that differ from mainstream dogma? Will she have access to a multidisciplinary team of collaborators whom she can access easily and frequently? Will she be able to integrate her model system with patients and the clinic? Will she be properly rewarded for participating in the difficult task of translational biology and medicine? Will she be in a supportive and helpful environment that encourages her to pursue new ideas and actively identifies and eliminates bureaucratic inefficiency wherever it exists?
These are the questions that matter for the next generation of investigators and for the next generation of leaders.

Certainly, an efficient translational research system that turns scientific discoveries and knowledge into useful products, procedures, and drugs for society is laudable and universally supported. Everyone wants more cures, new devices, increased manufacturing, and economic development-a cornucopia of good things-and these desires generate some urgency to make the system more efficient.

But, the urgency of today may not be enough. Looking ahead, the need to improve the translational ecosystem may be more than just about allowing patients to live a little longer or a little better, or producing the latest widget that drives a quarterly earnings statement, as important as those aims are.

The need may become extremely urgent.

Circling back to the two historically successful translational efforts of the 20th century mentioned at the beginning of the paper, antibiotics and insulin, one sees there is still much work to do in the 21st century. There has been an explosion in the incidence of diabetes and related obesity, inducing significant morbidity and mortality in populations worldwide, risking a dramatic increase in healthcare costs. In addition, we live in a dangerous microbial world, with threats that are both natural and man-made. The 20th century was one of remarkable progress in treating infectious diseases $[27,28,188,191]$. But the prospects for the next century are less clear due to emerging antibiotic resistance. Already, there are cracks in the antibiotic wall and the future here is murky [192].

Perhaps the last century was an anomaly. Perhaps we are destined to return to destructive plagues and epidemics of chronic diseases-or perhaps not-maybe a maximally efficient and productive translational research system will keep society one-step ahead in the game.

\section{Appendix}

\section{Relevant Websites}

\section{Challenges}

http:/www.theglobeandmail.com/globe-debate/whyscience-has-to-promise-profits/article4210388/

http://pipeline.corante.com/archives/2014/01/10/a new_look_at_clinical_attrition.php

http://blogs.wsj.com/health/2011/05/20/sanofis-zerhouni-on-translational-research-no-simple-solution/

http://pipeline.corante.com/archives/2011/05/24/maybe_it_really_is_that_hard.php

http://www.nature.com/news/specials/translationalresearch/index.html—editorial

http://www.the-scientist.com/?articles.view/articleNo/37346/title/Opinion-Translational-Research-inCrisis/.

New Ideas and Methods

http://news.sciencemag.org/2011/10/tech-entrepreneur-offers-grants-indie-science 
http://blogs.nature.com/news/2011/07/national_academies_panel_ponde.html

http://www.fastercures.org/

http://c-path.org/

http://www.cancerresearch.org/

http://www.nih.gov/science/amp/index.htm.

\section{Definitions}

http://www.cancer.gov/researchandfunding/trwg /TRWG-definition-and-TR-continuum

http://translationalhealthscience.com/index.html

http://www.tcrn.unsw.edu.au/translational-researchdefinitions

http://ctri.ucsd.edu/about/Pages/AboutTranslationalResearch.aspx.

\section{Diabetes and Insulin}

http://www.medicalnewstoday.com/info/diabetes /discoveryofinsulin.php

http://www.med.uni-giessen.de/itr/history/inshist. html

http://www.nobelprize.org/nobel_prizes/medicine /laureates/1923/

http://link.library.utoronto.ca/insulin/

http://www.littletree.com.au/dna.htm.

\section{Biotechnology and the Translational Milieu}

http://www.gene.com/media/press-releases/4160/1978-09-06/first-successful-laboratory-production-o http://www.europabio.org/what-biotechnology http://www.oecd.org/sti/biotech/keybiotechnologyindicators.htm

http://news.yahoo.com/dont-federal-science-grantedop-ed-171126844.html

http://careers.bmj.com/careers/advice/view-article. html?id=2607

http://bits.blogs.nytimes.com/2010/05/17/grove-backsan-engineers-approach-to-medicine/?ref=technology

http://www.researchamerica.org/

http://www.eutranslationalmedicine.org/

http://www.tcrn.unsw.edu.au/about-tcrn

http://www.ctsi.pitt.edu/

http://www.actscience.org/

http://ctsi.psu.edu/

http://www.economist.com/node/1476653

http://www.newsweek.com/why-dont-more-medical-discoveries-become-cures-72475 http:/healthland.time.com/2013/03/21/cancer-dreamteams-road-to-a-cure/

http://healthland.time.com/2013/04/01/the-conspiracy-to-end-cancer/

http://www.ncats.nih.gov/research/cts/cts.html

http://www.ctsacentral.org

http://www.nlm.nih.gov/ep/pathway.html

http://www.nhlbi.nih.gov/funding/training/redbook /phdk99r00.htm

http://sciencecareers.sciencemag.org/career_magazine /previous_issues/articles/2013_05_28/caredit.a1300113

http://sciencecareers.sciencemag.org/career_magazine /previous_issues/articles/2012_12_14/caredit.a1200136.

Transistor

http://www.pbs.org/transistor/albuml/

http://business.time.com/2012/03/21/how-bell-labsinvented-the-world-we-live-in-today/.

Integration of Models

http://emice.nci.nih.gov/

http://www.nih.gov/science/models/

http://www.journals.elsevier.com/journal-of-comparative-pathology/

http://www.vetmed.ucdavis.edu/comppath/index.html http://pathology.ucsd.edu/comparative_pathology. htm

http://www.springer.com/medicine/pathology/jour$\mathrm{nal} / 580$

http://www.hopkinsmedicine.org/mcp/Comparative Pathology/

http://ccr.cancer.gov/resources/training/applications /programInformation.asp

http://nih-cbstp.nci.nih.gov/index.asp

http://biospecimens.cancer.gov/default.asp

http://www.chtn.nci.nih.gov/

http://www.isber.org/

http://www.abrn.net/.

Reproducibility of Scientific Results

http://www.nature.com/news/psychologists-strike-ablow-for-reproducibility-1.14232

http://www.genengnews.com/gen-news-highlights / report-underscores-need-for-standards-in-life-science-research/81249236/

http://www.sfgate.com/health/article/Bad-sciencethat-slips-by-can-be-tough-to-refute-4978760.php 
http://www.nature.com/news/announcement-reducing-our-irreproducibility-1.12852

http://news.sciencemag.org/policy/2014/01/nihtakes-steps-improve-reproducibility

http://www.nytimes.com/2014/01/21/science/newtruths-that-only-one-can-see.html?_r=0.

\section{NIH Clinical Center}

http://clinicalcenter.nih.gov/about/news/annivers60. shtml

http://history.nih.gov/exhibits/beacon/.

\section{Disclaimer}

Michael R. Emmert-Buck is a translational researcher with twenty years of experience in laboratory and clinical studies, as well as with successful biotechnology company start-ups, both privately and in his role as a principal investigator in the NIH intramural program. The paper was written in his personal capacity and the views do not necessarily represent those of the Department of Health and Human Services, National Institutes of Health, or U.S. Public Health Service.

\section{Conflict of Interests}

The author declares that there is no conflict of interests regarding the publication of this paper.

\section{References}

[1] E. Abraham, F. M. Marincola, Z. Chen, and X. Wang, "Clinical and translational medicine: integrative and practical science," Clinical and Translational Medicine, vol. 1, article 1, 2012.

[2] D. G. Contopoulos-Ioannidis, G. A. Alexiou, T. C. Gouvias, and J. P. A. Ioannidis, "Medicine: life cycle of translational research for medical interventions," Science, vol. 321, no. 5894, pp. 12981299,2008

[3] H. Hörig, E. Marincola, and F. M. Marincola, "Obstacles and opportunities in translational research," Nature Medicine, vol. 11, no. 7, pp. 705-708, 2005.

[4] K. I. Kaitin and J. A. Dimasi, "Pharmaceutical innovation in the 21st century: new drug approvals in the first decade, 20002009," Clinical Pharmacology and Therapeutics, vol. 89, no. 2, pp. 183-188, 2011.

[5] M. J. Khoury, M. Gwinn, and J. P. A. Ioannidis, "The emergence of translational epidemiology: from scientific discovery to population health impact," American Journal of Epidemiology, vol. 172, no. 5, pp. 517-524, 2010.

[6] M. N. Liebman and F. M. Marincola, "Expanding the perspective of translational medicine: the value of observational data," Journal of Translational Medicine, vol. 10, no. 1, article 61, 2012.

[7] A. M. Feldman, "Does academic culture support translational research?" Clinical and Translational Science, vol. 1, no. 2, pp. 87-88, 2008.

[8] M. Scudellari, "The profits of nonprofit. The suprising results when drug development and altruism collide," The Scientist, article 25, 2010.
[9] G. Will, Rev the scientific engine, Washington Post 2011.

[10] J. C. Greenwood, "Biotechnology: delivering on the promise," Science Translational Medicine, vol. 2, no. 13, p. 13cml, 2010.

[11] J. P. A. Ioannidis, "Materializing research promises: opportunities, priorities and conflicts in translational medicine," Journal of Translational Medicine, vol. 2, article 5, 2004.

[12] S. P. Mankoff, C. Brander, S. Ferrone, and F. M. Marincola, "Lost in translation: obstacles to translational medicine," Journal of Translational Medicine, vol. 2, article 14, 2004.

[13] F. M. Marincola, "The trouble with translational medicine," Journal of Internal Medicine, vol. 270, no. 2, pp. 123-127, 2011.

[14] R. B. Nussenblatt, F. M. Marincola, and A. N. Schechter, "Translational Medicine-doing it backwards," Journal of Translational Medicine, vol. 8, article 12, 2010.

[15] J. S. Pober, C. S. Neuhauser, and J. M. Pober, "Obstacles facing translational research in academic medical centers," FASEB Journal, vol. 15, no. 13, pp. 2303-2313, 2001.

[16] M. Hay, D. W. Thomas, J. L. Craighead, C. Economides, and J. Rosenthal, "Clinical development success rates for investigational drugs," Nature Biotechnology, vol. 32, pp. 40-51, 2014.

[17] I. G. Mills and R. B. Sykes, "Taking risks with translational research," Science Translational Medicine, vol. 2, no. 24, p. 24cm10, 2010.

[18] M. R. Emmert-Buck, "An NIH intramural percubator as a model of academic-industry partnerships: from the beginning of life through the valley of death," Journal of Translational Medicine, vol. 9, article 54, 2011.

[19] J. Kaiser, "Rejecting 'big science'tag, collins sets five themes for NIH," Science, vol. 325, no. 5943, p. 927, 2009.

[20] B. H. Littman, L. di Mario, M. Plebani, and F. M. Marincola, "What's next in translational medicine?" Clinical Science, vol. 112 , no. 3-4, pp. 217-227, 2007.

[21] X. Wu, F. M. Marincola, M. N. Liebman, and X. Wang, "A global resource to translational medicine: the International Park of Translational Medicine and BioMedicine (IPTBM)," Journal of Translational Medicine, vol. 11, no. 1, article 8, 2013.

[22] T. A. Golper and H. I. Feldman, "New challenges and paradigms for mid-career faculty in academic medical centers: key strategies for success for mid-career medical school faculty," Clinical Journal of the American Society of Nephrology, vol. 3, no. 6, pp. $1870-1874,2008$

[23] E. Dolgin, "Collins sets out his vision for the NIH," Nature, vol. 460, no. 7258, p. 939, 2009.

[24] C. Skarke and G. A. FitzGerald, "Training translators for smart drug discovery," Science Translational Medicine, vol. 2, no. 26, p. $26 \mathrm{~cm} 12,2010$.

[25] S. H. Woolf, "The meaning of translational research and why it matters," Journal of the American Medical Association, vol. 299, no. 2, pp. 211-213, 2008.

[26] D. M. Rubio, E. E. Schoenbaum, L. S. Lee et al., "Defining translational research: implications for training," Academic Medicine, vol. 85, no. 3, pp. 470-475, 2010.

[27] A. Fleming, "On the antibacterial action of cultures of a penicillium, with special reference to their use in the isolation of B. influenzae," Reviews of Infectious Diseases, vol. 2, no. 1, pp. 129-139, 1980.

[28] F. Diggins, The True History of the Discovery of Penicillin by Alexander Fleming, Biomedical Scientist, Insititute of Biomedical Sciences, London, 2003, Originally published in the Imperial College School of Medicine Gazette. 
[29] I. Murray, "Paulescu and the isolation of insulin," Journal of the History of Medicine and Allied Sciences, vol. 26, pp. 150-157, 1971.

[30] P. G. Katsoyannis, K. Fukuda, A. Tometsko, K. Suzuki, and M. Tilak, "The synthesis of the B-chain of insulin and its combination with natural or synthetic A-chain to generate insulin activity," Journal of the American Chemical Society, vol. 86, no. 5, pp. 930-932, 1964.

[31] F. G. Banting, J. B. Collip, W. R. Campbell, and A. A. Fletcher, "Pancreatic extracts in the treatment of diabetes mellitus," Canadian Medical Association Journal, vol. 12, pp. 141-146, 1922.

[32] A. Wollmer, M. Federwisch, and P. de Meyts, Insulin \& Related Proteins Structure to Function and Pharmacology, Kluwer Academic Publishers, Boston, Mass, USA, 2002.

[33] M. F. Dunn, "Zinc-ligand interactions modulate assembly and stability of the insulin hexamer-a review," BioMetals, vol. 18, no. 4, pp. 295-303, 2005.

[34] B. T. Layden and W. L. Lowe Jr., "G-protein-coupled receptors, pancreatic islets, and diabetes," Nature Education, vol. 3, article 13, 2010.

[35] D. X. Brown, E. L. Butler, and M. Evans, "Lixisenatide as addon therapy to basal insulin," Drug Design, Development and Therapy, vol. 8, pp. 25-38, 2013.

[36] D. Constantin-Teodosiu, "Regulation of muscle pyruvate dehydrogenase complex in insulin resistance: effects of exercise and dichloroacetate," Diabetes and Metabolism Journal, vol. 37, pp. 301-314, 2013.

[37] A. King, "Integrating advances in insulin into clinical practice: advances In insulin formulations," The Journal of Family Practice, vol. 62, pp. S9-S17, 2013.

[38] C. Maria Rotella, L. Pala, and E. Mannucci, "Role of insulin in the type 2 diabetes therapy: past, present and future," International Journal of Endocrinology and Metabolism, vol. 11, pp. 137-144, 2013.

[39] K. M. A. Gartland, F. Bruschi, M. Dundar, P. B. Gahan, M. P. Viola Magni, and Y. Akbarova, "Progress towards the 'Golden Age'of biotechnology," Current Opinion in Biotechnology, vol. 24, no. 1, pp. S6-S13, 2013.

[40] B. M. Silber, "Driving drug discovery: the fundamental role of academic labs," Science Translational Medicine, vol. 2, no. 30, p. $30 \mathrm{~cm} 16,2010$.

[41] A. J. Stevens, J. J. Jensen, K. Wyller, P. C. Kilgore, S. Chatterjee, and M. L. Rohrbaugh, "The role of public-sector research in the discovery of drugs and vaccines," The New England Journal of Medicine, vol. 364, no. 6, pp. 535-541, 2011.

[42] K. Debackere and R. Veugelers, "The role of academic technology transfer organizations in improving industry science links," Research Policy, vol. 34, no. 3, pp. 321-342, 2005.

[43] A. M. Boccanfuso, "Why university-industry partnerships matter," Science Translational Medicine, vol. 2, no. 51, p. 51cm25, 2010.

[44] G. Evans and F. Austin, "Collaborations among academia, government, and industry in the diagnostics space: barriers and some ideas for solutions," Science Translational Medicine, vol. 2, no. $63,2010$.

[45] L. M. Portilla and B. Alving, "Reaping the benefits of biomedical research: partnerships required," Science Translational Medicine, vol. 2, no. 35, p. 35cm17, 2010.

[46] K. Handelsman, "A translational research niche for small business innovation research grants," Science Translational Medicine, vol. 1, no. 5, p. 5cm6, 2009.
[47] R. Klausner, "Translational science: a view from a biotechnology investor," Science Translational Medicine, vol. 2, no. 34, p. 34ed3, 2010.

[48] L. Serrano, "Synthetic biology: promises and challenges," Molecular Systems Biology, vol. 3, article 158, 2007.

[49] H. O. Smith, C. A. Hutchison III, C. Pfannkoch, and J. C. Venter, "Generating a synthetic genome by whole genome assembly: $\varphi \mathrm{X} 174$ bacteriophage from synthetic oligonucleotides," Proceedings of the National Academy of Sciences of the United States of America, vol. 100, no. 26, pp. 15440-15445, 2003.

[50] D. J. Segal and J. F. Meckler, "Genome engineering at the dawn of the golden age," Annual Review of Genomics and Human Genetics, vol. 14, pp. 135-158, 2013.

[51] L.-Y. Zhang, S.-H. Chang, and J. Wang, "How to make a minimal genome for synthetic minimal cell," Protein \& Cell, vol. 1, no. 5, pp. 427-434, 2010.

[52] M. A. O'Malley, A. Powell, J. F. Davies, and J. Calvert, "Knowledge-making distinctions in synthetic biology," BioEssays: News and Reviews in Molecular, Cellular and Developmental Biology, vol. 30, no. 1, pp. 57-65, 2008.

[53] D. Balke, C. Wichert, B. Appel, and S. Muller, "Generation and selection of ribozyme variants with potential application in protein engineering and synthetic biology," Applied Microbiology and Biotechnology, vol. 98, no. 8, pp. 3389-3399, 2014.

[54] H. Ye, D. Aubel, and M. Fussenegger, "Synthetic mammalian gene circuits for biomedical applications," Current Opinion in Chemical Biology, vol. 17, no. 6, pp. 910-917, 2013.

[55] A. V. Bryksin, A. C. Brown, M. M. Baksh, M. G. Finn, and T. H. Barker, "Learning from nature-novel synthetic biology approaches for biomaterial design," Acta Biomaterialia, vol. 10, no. 4, pp. 1761-1769, 2014.

[56] V. Singh, "Recent advancements in synthetic biology: current status and challenges," Gene, vol. 535, pp. 1-11, 2014.

[57] C. M. Agapakis, "Designing synthetic biology," ACS Synthetic Biology, vol. 3, no. 3, pp. 121-128, 2014.

[58] L. B. Scharff and R. Bock, "Emerging tools for synthetic biology in plants," The Plant Journal, vol. 78, no. 5, pp. 783-798, 2014.

[59] R. Rekhi and A. A. Qutub, "Systems approaches for synthetic biology: a pathway toward mammalian design," Frontiers in Physiology, vol. 4, article 285, 2013.

[60] K. H. Lee and D. M. Kim, "Applications of cell-free protein synthesis in synthetic biology: interfacing bio-machinery with synthetic environments," Biotechnology Journal, vol. 8, no. 11, pp. 1292-1300, 2013.

[61] H. Kim and E. Gelenbe, "G-networks towards synthetic biology: a brief review," in Proceedings of the Annual International Conference of the IEEE Engineering in Medicine and Biology Society IEEE Engineering in Medicine and Biology Society Conference, pp. 579-583, 2013.

[62] W. Bacchus, D. Aubel, and M. Fussenegger, "Biomedically relevant circuit-design strategies in mammalian synthetic biology," Molecular Systems Biology, vol. 9, article 691, 2013.

[63] M. Kalos and C. H. June, "Adoptive T cell transfer for cancer immunotherapy in the era of synthetic biology," Immunity, vol. 39, no. 1, pp. 49-60, 2013.

[64] B.-R. Lee, S. Cho, Y. Song, S. C. Kim, and B.-K. Cho, "Emerging tools for synthetic genome design," Molecules and Cells, vol. 35, no. 5, pp. 359-370, 2013.

[65] J. A. J. Arpino, E. J. Hancock, J. Anderson et al., "Tuning the dials of synthetic biology," Microbiology, vol. 159, no. 7, pp. 1236-1253, 2013. 
[66] M. G. J. de Vos, F. J. Poelwijk, and S. J. Tans, "Optimality in evolution: New insights from synthetic biology," Current Opinion in Biotechnology, vol. 24, no. 4, pp. 797-802, 2013.

[67] J. A. Gimpel, E. A. Specht, D. R. Georgianna, and S. P. Mayfield, "Advances in microalgae engineering and synthetic biology applications for biofuel production," Current Opinion in Chemical Biology, vol. 17, no. 3, pp. 489-495, 2013.

[68] B. J. Karas, B. Molparia, J. Jablanovic et al., "Assembly of eukaryotic algal chromosomes in yeast," Journal of Biological Engineering, vol. 7, article 30, 2013.

[69] M. G. Montague, C. Lartigue, and S. Vashee, "Synthetic genomics: potential and limitations," Current Opinion in Biotechnology, vol. 23, no. 5, pp. 659-665, 2012.

[70] J. I. Glass, N. Assad-Garcia, N. Alperovich et al., "Essential genes of a minimal bacterium," Proceedings of the National Academy of Sciences of the United States of America, vol. 103, no. 2, pp. 425-430, 2006.

[71] E. Pennisi, "Venter cooks up a synthetic genome in record time," Science, vol. 302, no. 5649, article 1307, 2003.

[72] M. Schmidt, H. Torgersen, A. Ganguli-Mitra, A. Kelle, A. Deplazes, and N. Biller-Andorno, "SYNBIOSAFE e-conference: online community discussion on the societal aspects of synthetic biology," Systems and Synthetic Biology, vol. 2, no. 1-2, pp. 7-17, 2008.

[73] A. Kelle, "Ensuring the security of synthetic biology-towards a 5p governance strategy," Systems and Synthetic Biology, vol. 3, no. 1, pp. 85-90, 2009.

[74] Y. Joly, G. Koutrikas, A.-M. Tassé et al., "Regulatory approval for new pharmacogenomic tests: A comparative overview," Food and Drug Law Journal, vol. 66, no. 1, pp. 1-24, 2011.

[75] S. H. Yim and Y. J. Chung, "Introduction to international ethical standards related to genetics and genomics," Genomics \& Informatics, vol. 11, pp. 218-223, 2013.

[76] E. Shapiro, T. Biezuner, and S. Linnarsson, "Single-cell sequencing-based technologies will revolutionize wholeorganism science," Nature Reviews Genetics, vol. 14, no. 9, pp. 618-630, 2013.

[77] C. H. Wade, B. A. Tarini, and B. S. Wilfond, "Growing up in the genomic era: implications of whole-genome sequencing for children, families, and pediatric practice," Annual Review of Genomics and Human Genetics, vol. 14, pp. 535-555, 2013.

[78] T. Pang, "Genomics for public health improvement: relevant international ethical and policy issues around genome-wide association studies and biobanks," Public Health Genomics, vol. 16, no. 1-2, pp. 69-72, 2013.

[79] E. R. Mardis, "Next-generation sequencing platforms," Annual Review of Analytical Chemistry, vol. 6, pp. 287-303, 2013.

[80] B. Dan and P. Baxter, "Paediatric neurology: a year of DNA technology," Lancet Neurology, vol. 13, pp. 16-18, 2014.

[81] V. G. Sankaran and P. G. Gallagher, "Applications of highthroughput DNA sequencing to benign hematology," Blood, vol. 122, pp. 3575-3582, 2013.

[82] Y. Yang, R. Liu, H. Xie et al., "Advances in nanopore sequencing technology," Journal of Nanoscience and Nanotechnology, vol. 13, no. 7, pp. 4521-4538, 2013.

[83] R. Normand and I. Yanai, "An introduction to high-throughput sequencing experiments: design and bioinformatics analysis," Methods in Molecular Biology, vol. 1038, pp. 1-26, 2013.

[84] F. S. Ong, J. C. Lin, K. Das, D. S. Grosu, and J.-B. Fan, “Translational utility of next-generation sequencing," Genomics, vol. 102, no. 3, pp. 137-139, 2013.
[85] M. Levy-Sakin and Y. Ebenstein, "Beyond sequencing: optical mapping of DNA in the age of nanotechnology and nanoscopy," Current Opinion in Biotechnology, vol. 24, no. 4, pp. 690-698, 2013.

[86] J. F. Thompson and J. S. Oliver, "Mapping and sequencing DNA using nanopores and nanodetectors," Electrophoresis, vol. 33, no. 23, pp. 3429-3436, 2012.

[87] B. Merriman, I. Torrent, and J. M. Rothberg, "Progress in ion torrent semiconductor chip based sequencing," Electrophoresis, vol. 33, no. 23, pp. 3397-3417, 2012.

[88] M. Tuna and C. I. Amos, "Genomic sequencing in cancer," Cancer Letters, vol. 340, pp. 161-170, 2013.

[89] S. Fox, S. Filichkin, and T. C. Mockler, "Applications of ultrahigh-throughput sequencing," Methods in Molecular Biology, vol. 553, pp. 79-108, 2009.

[90] Y. Bromberg, "Building a Genome Analysis Pipeline to Predict Disease Risk and Prevent Disease," Journal of Molecular Biology, vol. 425, pp. 3993-4005, 2013.

[91] J. M. Johnsen, D. A. Nickerson, and A. P. Reiner, "Massively parallel sequencing: the new frontier of hematologic genomics," Blood, vol. 122, pp. 3268-3275, 2013.

[92] D. C. Koboldt, K. M. Steinberg, D. E. Larson, R. K. Wilson, and E. R. Mardis, "The next-generation sequencing revolution and its impact on genomics," Cell, vol. 155, pp. 27-38, 2013.

[93] I. R. Watson, K. Takahashi, P. A. Futreal, and L. Chin, "Emerging patterns of somatic mutations in cancer," Nature Reviews Genetics, vol. 14, pp. 703-718, 2013.

[94] L. Wang and D. A. Wheeler, "Genomic sequencing for cancer diagnosis and therapy," Annual Review of Medicine, vol. 65, pp. 33-48, 2014.

[95] Y. R. Li, J. E. Levine, H. Hakonarson, and B. J. Keating, "Making the genomic leap in HCT: application of secondgeneration sequencing to clinical advances in hematopoietic cell transplantation," European Journal of Human Genetics, vol. 22, pp. 715-723, 2014.

[96] K. Davies, “The era of genomic medicine," Clinical Medicine, vol. 13, pp. 594-601, 2013.

[97] E. K. Bancroft, "How advances in genomics are changing patient care," The Nursing Clinics of North America, vol. 48, pp. 557-569, 2013.

[98] F. B. de Abreu, W. A. Wells, and G. J. Tsongalis, “The emerging role of the molecular diagnostics laboratory in breast cancer personalized medicine," The American Journal of Pathology, vol. 183, pp. 1075-1083, 2013.

[99] L. G. Biesecker, "Hypothesis-generating research and predictive medicine," Genome Research, vol. 23, no. 7, pp. 1051-1053, 2013.

[100] S. Kamalakaran, V. Varadan, A. Janevski et al., "Translating next generation sequencing to practice: opportunities and necessary steps," Molecular Oncology, vol. 7, no. 4, pp. 743-755, 2013.

[101] J. J. McCarthy, H. L. McLeod, and G. S. Ginsburg, "Genomic medicine: a decade of successes, challenges, and opportunities," Science Translational Medicine, vol. 5, no. 189, p. 189sr4, 2013.

[102] R. Simon and S. Roychowdhury, "Implementing personalized cancer genomics in clinical trials," Nature Reviews Drug Discovery, vol. 12, no. 5, pp. 358-369, 2013.

[103] L. A. Garraway, "Genomics-driven oncology: framework for an emerging paradigm," Journal of Clinical Oncology, vol. 31, no. 15, pp. 1806-1814, 2013.

[104] S. Tsuji, "The neurogenomics view of neurological diseases," JAMA Neurology, vol. 70, no. 6, pp. 689-694, 2013. 
[105] M. J. Annala, B. C. Parker, W. Zhang, and M. Nykter, "Fusion genes and their discovery using high throughput sequencing," Cancer Letters, vol. 340, pp. 192-200, 2013.

[106] R. R. Gullapalli, K. V. Desai, L. Santana-Santos, J. A. Kant, and M. J. Becich, "Next generation sequencing in clinical medicine: challenges and lessons for pathology and biomedical informatics," Journal of Pathology Informatics, vol. 3, article 40, 2012.

[107] C. Brander and F. M. Marincola, "AAAS joins the Translational Medicine family," Journal of Translational Medicine, vol. 7, article 32, 2009.

[108] X. Chen, R. Andersson, W. C. Cho et al., "The international effort: building the bridge for translational medicine: report of the 1st International Conference of Translational Medicine (ICTM)," Clinical and Translational Medicine, vol. 1, no. 1, article 15, 2012.

[109] J. A. DiMasi, R. W. Hansen, H. G. Grabowski, and L. Lasagna, "Cost of innovation in the pharmaceutical industry," Journal of Health Economics, vol. 10, no. 2, pp. 107-142, 1991.

[110] J. A. DiMasi, R. W. Hansen, and H. G. Grabowski, "The price of innovation: new estimates of drug development costs," Journal of Health Economics, vol. 22, no. 2, pp. 151-185, 2003.

[111] M. E. Hughes, J. Peeler, and J. B. Hogenesch, "Network dynamics to evaluate performance of an academic institution," Science Translational Medicine, vol. 2, no. 53, Article ID 53ps49, 2010.

[112] M. Qian, D. Wu, E. Wang et al., "Development and promotion in translational medicine: perspectives from 2012 sino-american symposium on clinical and translational medicine," Clinical and Translational Medicine, vol. 1, article 25, 2012.

[113] A. Cambrosio, P. Keating, S. Mercier, G. Lewison, and A. Mogoutov, "Mapping the emergence and development of translational cancer research," European Journal of Cancer, vol. 42, no. 18, pp. 3140-3148, 2006.

[114] A. Rajan, R. Sullivan, S. Bakker, and W. H. van Harten, "Critical appraisal of translational research models for suitability in performance assessment of cancer centers," The Oncologist, vol. 17, no. 12, pp. e48-e57, 2012.

[115] W. Trochim, C. Kane, M. J. Graham, and H. A. Pincus, "Evaluating translational research: a process marker model," Clinical and Translational Science, vol. 4, no. 3, pp. 153-162, 2011.

[116] E. A. Zerhouni, "Space for the cures: science launches a new journal dedicated to translational research in biomedicine," Science Translational Medicine, vol. 1, no. 1, p. led1, 2009.

[117] E. G. Nabel, "On board with the cures acceleration network," Science Translational Medicine, vol. 2, no. 32, p. 32ed2, 2010.

[118] H. J. Falk-Krzesinski, K. Börner, N. Contractor et al., "Advancing the science of team science," Clinical and Translational Science, vol. 3, no. 5, pp. 263-266, 2010.

[119] K. Börner, N. Contractor, H. J. Falk-Krzesinski et al., "A multilevel systems perspective for the science of team science," Science Translational Medicine, vol. 2, no. 49, p. 49cm24, 2010.

[120] D. C. Mowery, B. N. Sampat, and A. A. Ziedonis, "Learning to patent: institutional experience, learning, and the characteristics of U.S. University patents after the Bayh-Dole Act, 19811992," Management Science, vol. 48, no. 1, pp. 73-89, 2002.

[121] V. Loise and A. J. Stevens, “The Bayh-Dole act turns 30," Science Translational Medicine, vol. 2, no. 52, p. 52cm27, 2010.

[122] A. Colaianni and R. Cook-Deegan, "Columbia university's axel patents: technology transfer and implications for the Bayh-Dole Act," Milbank Quarterly, vol. 87, no. 3, pp. 683-715, 2009.
[123] R. Dalton, "Berkeley's energy deal with BP sparks unease," Nature, vol. 445, no. 7129, pp. 688-689, 2007.

[124] R. Jensen and M. Thursby, "Proofs and prototypes for sale: the licensing of University inventions," The American Economic Review, vol. 91, no. 1, pp. 240-259, 2001.

[125] S. A. Mian, "US university-sponsored technology incubators: an overview of management, policies and performance," Technovation, vol. 14, no. 8, pp. 515-528, 1994.

[126] N. R. Council, Managing University Intellectual Property in the Public Interest, The National Academies Press, Washington, DC, USA, 2010.

[127] R. G. Phillips, “Technology business incubators: how effective as technology transfer mechanisms?” Technology in Society, vol. 24, no. 3, pp. 299-316, 2002.

[128] J. Gertner, The Idea Factory: Bell Labs and the Great Age of American Innovation, Penguin, New York, NY, USA, 2012.

[129] M. Riordan and L. Hoddeson, Crystal Fire: the Invention of the Transistor and Birth of the Information Age, WW Norton, New York, NY, USA, 1998.

[130] W. F. Brinkman, D. E. Haggan, and W. W. Troutman, "A history of the invention of the transistor and where it will lead us," IEEE Journal of Solid-State Circuits, vol. 32, no. 12, pp. 1858-1864, 1997.

[131] S. J. Steele, "Working with the CTSA consortium: what we bring to the table," Science Translational Medicine, vol. 2, no. 63, p. $63 \mathrm{mr} 5,2010$.

[132] J. G. Thursby and M. C. Thursby, "Intellectual property. University licensing and the Bayh-Dole Act," Science, vol. 301, no. 5636, p. $1052,2003$.

[133] D. Blumenthal, E. G. Campbell, N. Causino, and K. S. Louis, "Participation of life science faculty in research relationships with industry," The New England Journal of Medicine, vol. 335, no. 23, pp. 1734-1739, 1996.

[134] R. Fini, N. Lacetera, and S. Shane, "Inside or outside the IP system? Business creation in academia," Research Policy, vol. 39, no. 8, pp. 1060-1069, 2010.

[135] R. A. Lowe and C. Gonzalez-Brambila, "Faculty entrepreneurs and research productivity," Journal of Technology Transfer, vol. 32, no. 3, pp. 173-194, 2007.

[136] A. Aneja, R. Esquitin, K. Shah et al., "Authors'self-declared financial conflicts of interest do not impact the results of major cardiovascular trials," Journal of the American College of Cardiology, vol. 61, pp. 1137-1143, 2013.

[137] S. V. Sharma, D. A. Haber, and J. Settleman, "Cell line-based platforms to evaluate the therapeutic efficacy of candidate anticancer agents," Nature Reviews Cancer, vol. 10, no. 4, pp. 241253, 2010.

[138] J. Mattern, M. Bak, E. W. Hahn, and M. Volm, "Human tumor xenografts as model for drug testing," Cancer Metastasis Reviews, vol. 7, no. 3, pp. 263-284, 1988.

[139] J. N. Weinstein, "Drug discovery: cell lines battle cancer," Nature, vol. 483, no. 7391, pp. 544-545, 2012.

[140] R. H. Shoemaker, "The NCI60 human tumour cell line anticancer drug screen," Nature Reviews Cancer, vol. 6, no. 10, pp. 813-823, 2006.

[141] U. McDermott, S. V. Sharma, and J. Settleman, "Highthroughput lung cancer cell line screening for genotypecorrelated sensitivity to an EGFR kinase inhibitor," Methods in Enzymology, vol. 438, pp. 331-341, 2008.

[142] J. Barretina, G. Caponigro, N. Stransky et al., "Addendum: The Cancer Cell Line Encyclopedia enables predictive modelling of anticancer drug sensitivity," Nature, vol. 483, pp. 603-607, 2012. 
[143] G. Kari, U. Rodeck, and A. P. Dicker, "Zebrafish: an emerging model system for human disease and drug discovery," Clinical Pharmacology and Therapeutics, vol. 82, no. 1, pp. 70-80, 2007.

[144] C. Chakraborty, C. H. Hsu, Z. H. Wen, C. S. Lin, and G. Agoramoorthy, "Zebrafish: a complete animal model for in vivo drug discovery and development," Current Drug Metabolism, vol. 10, no. 2, pp. 116-124, 2009.

[145] S. B. Hedges, "The origin and evolution of model organisms," Nature Reviews Genetics, vol. 3, no. 11, pp. 838-849, 2002.

[146] M. Jucker, "The benefits and limitations of animal models for translational research in neurodegenerative diseases," Nature Medicine, vol. 16, no. 11, pp. 1210-1214, 2010.

[147] C. G. Begley and L. M. Ellis, "Drug development: raise standards for preclinical cancer research," Nature, vol. 483, no. 7391, pp. 531-533, 2012.

[148] D. Alishekevitz, R. Bril, D. Loven et al., "Differential therapeutic effects of anti-VEGF-A antibody in different tumor models: implications for choosing appropriate tumor models for drug testing," Molecular Cancer Therapeutics, vol. 13, pp. 202-213, 2014.

[149] J.-P. Gillet, S. Varma, and M. M. Gottesman, "The clinical relevance of cancer cell lines," Journal of the National Cancer Institute, vol. 105, no. 7, pp. 452-458, 2013.

[150] A. F. Gazdar, B. Gao, and J. D. Minna, "Lung cancer cell lines: useless artifacts or invaluable tools for medical science?" Lung Cancer, vol. 68, no. 3, pp. 309-318, 2010.

[151] A. F. Gazdar, L. Girard, W. W. Lockwood, W. L. Lam, and J. D. Minna, "Lung cancer cell lines as tools for biomedical discovery and research," Journal of the National Cancer Institute, vol. 102, no. 17, pp. 1310-1321, 2010.

[152] J. Gandhi, J. Zhang, Y. Xie et al., "Alterations in genes of the EGFR signaling pathway and their relationship to EGFR tyrosine kinase inhibitor sensitivity in lung cancer cell lines," PLoS ONE, vol. 4, no. 2, Article ID e4576, 2009.

[153] J. L. Wilding and W. F. Bodmer, "Cancer cell lines for drug discovery and development," Cancer Research, vol. 74, pp. 23772384, 2014.

[154] J. Heyer, L. N. Kwong, S. W. Lowe, and L. Chin, "Non-germline genetically engineered mouse models for translational cancer research," Nature Reviews Cancer, vol. 10, no. 7, pp. 470-480, 2010.

[155] K. Garber, "From human to mouse and back: "tumorgraft" models surge in popularity," Journal of the National Cancer Institute, vol. 101, no. 1, pp. 6-8, 2009.

[156] S. Rottenberg and P. Borst, "Drug resistance in the mouse cancer clinic," Drug Resistance Updates, vol. 15, no. 1-2, pp. 81-89, 2012.

[157] H. C. Denroche, W. L. Quong, J. E. Bruin et al., "Leptin administration enhances islet transplant performance in diabetic mice," Diabetes, vol. 62, pp. 2738-2746, 2013.

[158] H. Dong, H. Huang, X. Yun et al., "Bilirubin increases insulin sensitivity in leptin-receptor deficient and diet-induced obese mice through suppression of ER stress and chronic inflammation," Endocrinology, vol. 155, no. 3, pp. 818-828, 2014.

[159] U. H. Neumann, S. Chen, Y. Y. Tam et al., "IGFBP2 is neither sufficient nor necessary for the physiological actions of leptin on glucose homeostasis in male ob/ob mice," Endocrinology, vol. 155, no. 3, pp. 16-25, 2014.

[160] H. J. Do, T. Jin, J. H. Chung, J. W. Hwang, and M. J. Shin, "Voglibose administration regulates body weight and energy intake in high fat-induced obese mice," Biochemical and Biophysical Research Communications, vol. 443, pp. 1110-1117, 2014.
[161] C. E. Koch, C. Lowe, D. Pretz, J. Steger, L. M. Williams, and A. Tups, "High fat diet induces leptin resistance," Journal of Neuroendocrinology, vol. 28, no. 2, pp. 58-67, 2013.

[162] K. M. Gamber, L. Huo, S. Ha, J. E. Hairston, S. Greeley, and C. Bjørbæk, "Over-expression of leptin receptors in hypothalamic POMC neurons increases susceptibility to diet-induced obesity," PLoS ONE, vol. 7, no. 1, Article ID e30485, 2012.

[163] C. Clemmensen, J. Chabenne, B. Finan et al., "GLP-1/glucagon co-agonism restores leptin responsiveness in obese mice chronically maintained on an obesogenic diet," Diabetes, vol. 63, no. 4, pp. 1422-1427, 2014.

[164] T. Roszer, T. Jozsa, E. D. Kiss-Toth, N. de Clerck, and L. Balogh, "Leptin receptor deficient diabetic $(\mathrm{db} / \mathrm{db})$ mice are compromised in postnatal bone regeneration," Cell and Tissue Research, vol. 356, no. 1, pp. 195-206, 2013.

[165] R. Guzman-Ruiz, N. Gomez-Hurtado, M. Gil-Ortega et al., "Remodeling of energy metabolism and absence of electrophysiological changes in the heart of obese hyperleptinemic mice. New insights into the pleiotropic role of leptin," Frontiers in Endocrinology, vol. 4, article 175, 2013.

[166] J. Benzler, Z. B. Andrews, C. Pracht et al., "Hypothalamic WNT signalling is impaired during obesity and reinstated by leptin treatment in male mice," Endocrinology, vol. 154, pp. 4737-4745, 2013.

[167] L. Zabeau, F. Peelman, and J. Tavernier, "Antagonising leptin: current status and future directions," Biological Chemistry, vol. 395, no. 5, pp. 499-514, 2014.

[168] P. D. Taylor, A. M. Samuelsson, and L. Poston, "Maternal obesity and the developmental programming of hypertension: a role for leptin," Acta Physiologica, vol. 210, no. 3, pp. 508-523, 2014.

[169] M. D. Klok, S. Jakobsdottir, and M. L. Drent, "The role of leptin and ghrelin in the regulation of food intake and body weight in humans: a review," Obesity Reviews, vol. 8, no. 1, pp. 21-34, 2007.

[170] J. Grasman, "Reconstruction of the drive underlying food intake and its control by leptin and dieting," PloS ONE, vol. 8, Article ID e74997, 2013.

[171] R. Muniyappa, R. J. Brown, A. Mari et al., "Effects of leptin replacement therapy on pancreatic beta-cell function in patients with lipodystrophy," Diabetes Care, vol. 37, no. 4, pp. 1101-1107, 2014.

[172] R. Z. Tom, P. M. Garcia-Roves, R. J. Sjogren et al., "Effects of AMPK activation on insulin sensitivity and metabolism in leptin-deficient ob/ob mice," Diabetes, vol. 63, no. 5, pp. 15601571, 2014.

[173] N. Chapnik, Y. Genzer, A. Ben-Shimon, M. Y. Niv, and O. Froy, "AMPK-derived peptides reduce blood glucose but lead to fat retention in the liver of obese mice," The Journal of Endocrinology, vol. 221, no. 1, pp. 89-99, 2014.

[174] E. Tuduri, H. C. Denroche, J. A. Kara, A. Asadi, J. K. Fox, and T. J. Kieffer, "Partial ablation of leptin signaling in mouse pancreatic alpha-cells does not alter either glucose or lipid homeostasis," American Journal of Physiology Endocrinology and Metabolism, vol. 306, no. 7, pp. E748-E755, 2014.

[175] H. C. Denroche, J. Levi, R. D. Wideman et al., "Leptin therapy reverses hyperglycemia in mice with streptozotocin-induced diabetes, independent of hepatic leptin signaling," Diabetes, vol. 60, no. 5, pp. 1414-1423, 2011.

[176] J. P. A. Ioannidis, "Contradicted and initially stronger effects in highly cited clinical research," Journal of the American Medical Association, vol. 294, no. 2, pp. 218-228, 2005.

[177] M. Wadman, "NIH mulls rules for validating key results," Nature, vol. 500, pp. 14-16, 2013. 
[178] K. K. Tsilidis, O. A. Panagiotou, E. S. Sena et al., "Evaluation of excess significance bias in animal studies of neurological diseases," PLoS Biology, vol. 11, no. 7, Article ID e1001609, 2013.

[179] F. S. Collins and L. A. Tabak, "Policy: NIH plans to enhance reproducibility," Nature, vol. 505, pp. 612-613, 2014.

[180] Y. Huang and R. Gottardo, "Comparability and reproducibility of biomedical data," Briefings in Bioinformatics, vol. 14, pp. 391401, 2013.

[181] J. Couzin-Frankel, "When mice mislead," Science, vol. 342, pp. 922-925, 2013.

[182] R. J. Traystman and P. S. Herson, "Misleading results: translational challenges," Science, vol. 343, pp. 369-370, 2014.

[183] M. McNutt, "Reproducibility," Science, vol. 343, no. 6168, article 229, 2014.

[184] M. Bissell, "Reproducibility: the risks of the replication drive," Nature, vol. 503, pp. 333-334, 2013.

[185] J. P. A. Ioannidis, "Why most published research findings are false," PLoS Medicine, vol. 2, no. 8, Article ID e124, 2005.

[186] B. ] Alberts, M. W. Kirschner, S. Tilghman, and H. Varmus, "Rescuing US biomedical research from its systemic flaws," Proceedings of the National Academy of Sciences, vol. 111, pp. 5773-5777, 2014.

[187] F. M. Marincola, "Translational medicine: a two-way road," Journal of Translational Medicine, vol. 1, article 1, 2003.

[188] S. K. Chatterjee and M. L. Rohrbaugh, "NIH inventions translate into drugs and biologics with high public health impact," Nature Biotechnology, vol. 32, pp. 52-58, 2014.

[189] S. Khot, B. Soon Park, and W. T. Longstreth Jr., "The vietnam war and medical research: untold legacy of the U.S. doctor draft and the NIH "yellow berets'”, Academic Medicine, vol. 86, no. 4, pp. 502-508, 2011.

[190] M. M. Gottesman, "The role of the NIH in nurturing clinicianscientists," The New England Journal of Medicine, vol. 368, no. 24, pp. 2249-2251, 2013.

[191] S. Broder, "Twenty-five years of translational medicine in antiretroviral therapy: promises to keep," Science Translational Medicine, vol. 2, no. 39, p. 39ps33, 2010.

[192] K. Lewis, "Platforms for antibiotic discovery," Nature Reviews Drug Discovery, vol. 12, no. 5, pp. 371-387, 2013. 



Submit your manuscripts at

http://www.hindawi.com

Journal of
Signal Transduction


The Scientific World Journal
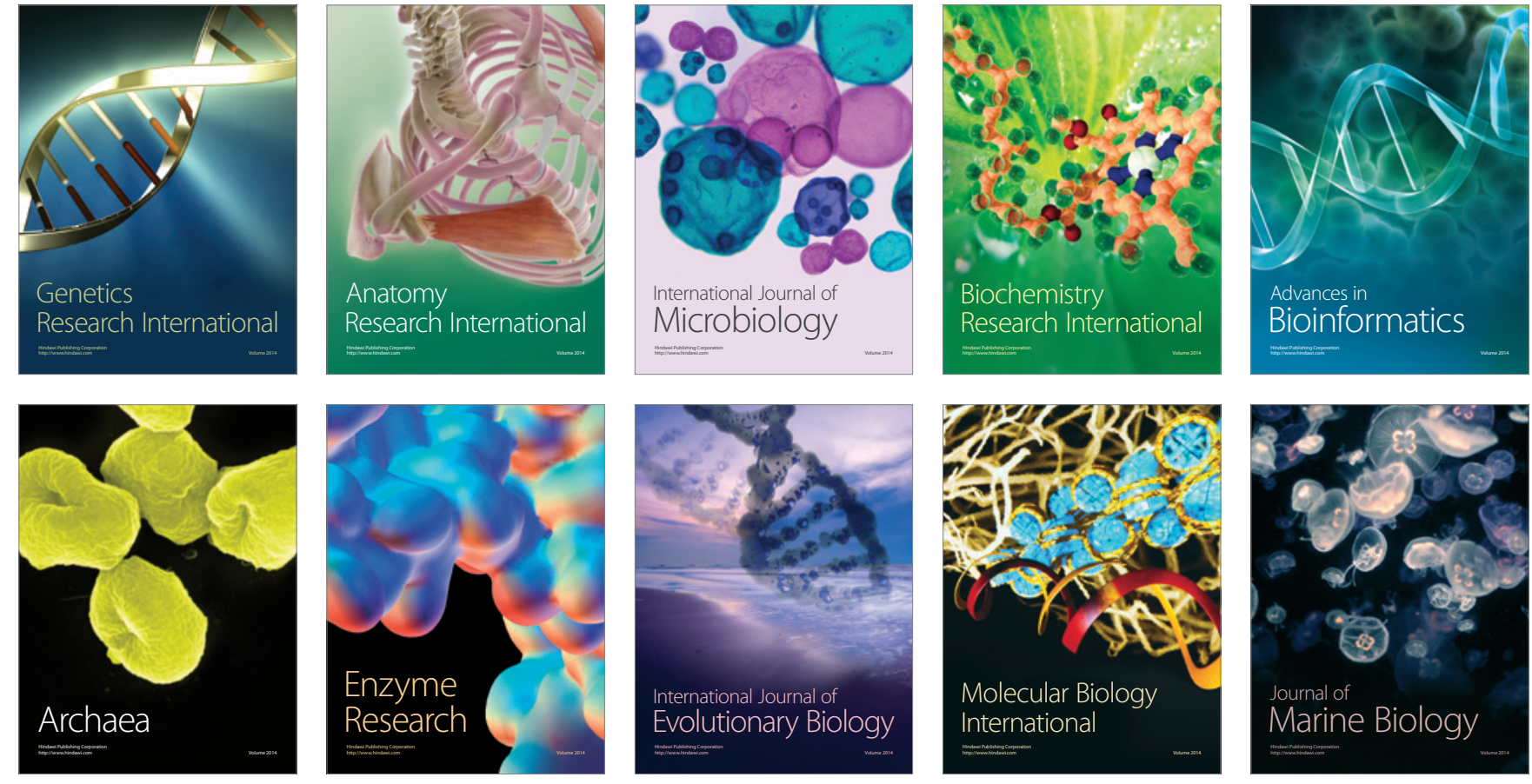